\title{
SANTIAGO MATAMOROS EN SEVILLA. MITO, ARTE Y DEVOCIÓN
}

\author{
SAINT JAMES THE MOOR-SLAYER IN SEVILLE. \\ MYTH, ART AND DEVOTION
}

Javier Gómez Darriba

Universidade de Santiago de Compostela

ABSTRACT • The city of Seville professed a great worship of Saint James the Moor-slayer between the $16^{\text {th }}$ and $18^{\text {th }}$ centuries. This study analyses the reasons why such a cult took root in Seville, converting the city into an authentic Jacobean capital. Likewise, it delves into an analysis of the artistic works that emerged there as a consequence of the worship of Saint James, with special attention devoted to the different motivations of it promoters for undertaking those works of art.

KEYWORDS: Saint James the Moor-slayer; Seville; Patronage of Spain; Chapter of Seville; Gonzalo Argote de Molina.

RESUMEN • La ciudad de Sevilla profesó un inmenso culto a Santiago Matamoros entre los siglos XVI y XVIII. Analizaremos las razones por las cuales dicha devoción arraigó en ella, convirtiéndola en una auténtica capital jacobea. Asimismo, estudiaremos las obras artísticas que allí surgieron por causa de dicho culto, haciendo hincapié en las distintas motivaciones de sus promotores por llevarlas a cabo.

PALABRAS CLAVES: Santiago Matamoros; Sevilla; Patronato de España; Cabildo de Sevilla, Gonzalo Argote de Molina. 
Resulta sorprendente que nunca se haya hecho el suficiente hincapié en la histórica vinculación de Santiago el Mayor con la ciudad de Sevilla, pues esta siempre ha sido un centro cultual jacobeo de primer orden. ${ }^{1}$ De ahí que aún hoy atesore tantas y tan brillantes imágenes del apóstol. Muchas de estas florecieron entre los siglos XVI y XVIII bajo su tipo iconográfico de Matamoros, y lo hicieron en tal cantidad y con tal notoriedad, que podemos afirmar sin temor a equivocarnos, que ninguna otra urbe peninsular, europea o americana, asistió a una gestación comparable. Los motivos por los cuales la Sevilla moderna exaltó a Santiago de forma tan manifiesta son múltiples. Por un lado, se consideraba que el origen cristiano de la ciudad estaba íntimamente ligado a la evangelización del apóstol en la Bética. Esta mítica tradición fue una constante en decenas de poblaciones españolas por entonces. En nuestro caso, se creía que Santiago había llevado a cabo la acción pastoral con su discípulo san Pío. Juntos delimitaron la diócesis hispalense y Santiago le designó primer obispo. Antes de conocer al apóstol, Pío había ejercido el oficio de escultor, especializándose en el modelado de figuras de barro; por ello se le atribuyó la hechura de la imagen titular del primer templo cristiano de Híspalis, puesto bajo la advocación jacobea de la Virgen del Pilar, primera patrona de la ciudad (de Espinosa de los Monteros, 1627: 38r-38v. Mena Calvo, 2010: 39. Linares, 2013: 63-64, 72. Ídem, 2014: 125-132). Ahora bien, obviando este mito y respaldándonos en las fuentes documentales probadas, el origen del culto a Santiago en Sevilla no se retrotrae hasta el siglo I, sino a la década de 1240, dentro del contexto reconquistador que procuraba el rey de Castilla y León Fernando III el Santo, cuyo ejército lo nutrían un buen número de caballeros de la Orden de Santiago liderados por el maestre Pelay Pérez Correa, quien hasta la toma de Sevilla de 1248 desempeñó un papel fundamental en el paulatino sometimiento de distintas plazas de la actual provincia hispalense. Asimismo, la Orden contribuyó a fijar los límites de la archidiócesis en el tercer cuarto del siglo XIII; y por si fuera poco, asumió la repoblación de vastos territorios conseguidos en época fernandina, en los que se asentó fundando parroquias, monasterios y encomiendas en las que ejerció jurisdicción. Tres de dichas encomiendas se hallaban cercanas a la capital, en pleno Aljarafe: la de Benazuza-Mures -hoy Villamanrique de la Condesa-, la de Villanueva del Ariscal y la de Castilleja de la Cuesta. A ellas habría que sumar la de Estepa y la de Santiago de la Espada, fundada esta última en Sevilla en 1409, y cuyo convento resultó el tercero en su jerarquía tras el de Santiago de Uclés y el de San Marcos de León (Peinado Santaella, 19761977: 181. Ladero Quesada, 1989: 16-18, 197. Rodríguez Blanco, 1979: 309. Ídem, 2012: 288-292, 297-301, 308-316, 322. Ídem, 2013: 278-285, 289-293, 301-310, 317). La citada Reconquista se ligaba al papel que venía desempañando Santiago desde la Alta Edad Media como patrono de la monarquía hispana; como santo valedor de la misma ante cualquier conflicto armado; y como el más férreo defensor de la fe católica contra distintos desvíos heréticos. De ahí su constante invocación frente a moros, moriscos, turcos otomanos, piratas berberiscos, reformados europeos, naturales de las Indias recién descubiertas, etc. Santiago también conformaba en Sevilla un guardián de la navegación, una faceta que compartía con

1. Este trabajo se enmarca dentro del proyecto del Ministerio de Economía, Industria y Competitividad Memoria, textos e imágenes. La recuperación del patrimonio perdido para la sociedad de Galicia HAR2014-53893-R, del que son investigadores principales Jesús A. Sánchez García y Alfredo Vigo Trasancos. También participa de la ayuda del Programa de consolidación de unidades de investigación competitivas do SUG, modalidade B: grupos con potencial de crecemento (GPC), concedida por la Xunta de Galicia al grupo de investigación GI-1510 HAAYDU de la Universidad de Santiago de Compostela, del que es coordinador Alfredo Vigo Trasancos y que tiene como ${ }^{\circ}$ de expediente ED413B 2016/003. Asimismo, amplía y mejora un estudio preliminar acerca del tema (Gómez Darriba: 2017b). Quiero agradecer a los investigadores Ofelia Rey Castelao, Lidwine Linares y Enric Olivares Torres, sus consejos y la amabilidad con que me brindaron bibliografía que desconocía. 
otros santos como san Telmo, san Nicolás de Bari o san Juan Nepomuceno, todos ellos de indiscutible devoción en la ciudad. La bienaventuranza local y estatal dependía del comercio marítimo-fluvial aquí establecido, puesto que constituyó durante siglos el único puerto de Indias por el que entraban las riquezas que abastecían el entramado político-económico de la Corona, de ahí la constante invocación a estos santos protectores marinos (Domínguez Ortiz, 1984. Morales Padrón, 1989).

Por otro lado, los arzobispos y el Cabildo también fomentaron la devoción al apóstol que había fundado su archidiócesis. Le tributaron obras artísticas muy sobresalientes, caso de un libro de coro miniado para sus festividades en la década de 1560, o de un retablo para su capilla catedralicia en el siglo XVII. En esta centuria salieron en defensa de Santiago con un empeño denodado, pues se opusieron rotundamente a que perdiese su exclusivo patronazgo sobre la Corona a costa de compartirlo con santa Teresa, y para ello bregaron con toda cuanta institución o personaje fue menester, al tiempo que emitieron distintos manuscritos e impresos en donde se hacían valer las virtudes jacobeas y se infravaloraban las teresianas. Por último, en 1630 festejaron el breve de Urbano VIII que zanjaba la polémica a favor de Santiago, y para ello mandaron colgar de la Giralda un gigantesco estandarte con la imagen del Matamoros que ondeó en el cielo sevillano. Conocidas estas circunstancias, trataremos de dar respuesta a las múltiples motivaciones que llevaron no solo a la Iglesia de Sevilla, sino también a renombrados nobles como Gonzalo Argote de Molina, a mercaderes locales, o a la Orden de Santiago, a contratar a grandes artistas del momento para erigir insignes obras a mayor gloria del apóstol.

\section{SANTIAGO MATAMOROS. LA RAZÓN DE SER DE UNA DEVOCIÓN}

Aunque la historiografía no termina de ponerse de acuerdo, parece que la concepción de Santiago como soldado de Cristo, o al menos como patrono de monarcas asturleoneses a título individual, se retrotrae hasta los siglos VIII y IX. Ya entonces confiaban en que la taumaturgia apostólica favorecía la Reconquista cristiana de la Península. Los reyes castellanos heredaron esta imprecación (Rey Castelao, 2006: 60-61. Herbers, 2006: 31-34. García Iglesias, 2011: 143), considerándolo desde el siglo XII como patrono del reino y defensor espiritual de Hispania. En dicha centuria se gestaron tres manuscritos que refrendaron su imagen caballeresca. El primero de ellos fue la Historia Silense o Seminense, surgida hacia 1110-1120 en el monasterio leonés de San Juan y San Pelayo. En ella se narra que durante tres días de 1064, el rey Fernando I acudió a la basílica compostelana para rogar auxilio al apóstol en la consecución de la plaza de Coimbra, petición que fructificó después de medio año de asedio. El día previo a la victoria, un peregrino griego que rezaba en el templo, se sorprendió de que otros como él invocasen a Santiago bajo la condición de soldado, pues creía que jamás la había tenido. Esa misma noche se le apareció el Hijo del Zebedeo mostrándole un caballo blanco, así como las llaves que al día siguiente llenarían de gloria al monarca, quien enterado de lo acaecido, retornó a Compostela para dar gracias al apóstol. El Liber Sancti Iacobi retoma el milagro de la Seminense dos decenios después, aunque incluyendo cambios, pues el peregrino griego pasa a convertirse en el obispo Esteban, por cuya boca se asegura que "Santiago daba la victoria a todos los que en la milicia le invocaban". Así pues, ninguna de las dos fuentes hace a Santiago partícipe directo en el combate, sino otorgante del triunfo. Llegado el tercer cuarto de siglo, se elabora otro documento en dicha

IMAGO, NÚM. 10, 2018, 143-173 
catedral compostelana que supondrá el empuje decisivo para su iconografía caballeresca, y a la vez, el origen de las futuras hagiografías, polémicas y pleitos suscitados en torno al Voto de Santiago. El canónigo Pedro Marcio redacta entonces el Privilegio de los Votos o Diploma de Ramiro, en el cual dicho monarca asturiano ruega que no quede en el olvido la ofrenda que había hecho al apóstol. Para ello, explica la génesis de la misma. Describe que previo su reinado, sus antecesores permitían al califato de Córdoba el abominable Tributo de las Cien Doncellas, por el cual podían servirse anualmente de un centenar de cristianas para consumar con ellas toda clase de atropellos. Con la intención de frenar este repulsivo compromiso, reunió en el año 844 a un selecto ejército y se encaminó hacia las riojanas tierras de Nájera y Albelda, donde los musulmanes le infligieron una aplastante derrota. Retirado al cerro de Clavijo, esa misma noche se le apareció en sueños el apóstol, recordándole que Hispania seguía bajo su amparo: "Beatus Iacobus hispanorum protector», e instándole a tomar las armas de nuevo. El rey se lo comunicó a sus tropas y estas acudieron a la lid colmadas de entusiasmo, manifestándose Santiago en la refriega como lo había dictado: «me veréis constantemente sobre un caballo blanco con una figura blanquecina enorme y llevando su estandarte blanco muy grande». Este prodigioso advenimiento trajo la victoria a los cristianos (Sicart Giménez, 1982: 15-21, 23. Barrios Gutiérrez, 1989: 72-83. Cabrillana Ciézar, 1999: 13, 33, 55, 57, 73-74. Moralejo Laso, 2004: 375-377. Fernández Gallardo, 2005: 139150. Domínguez García, 2008: 81-86. Linares, 2008: 183-189. Olivares Torres, 2011: 39-47. Ídem, 2015: 354-358, 361-368). ${ }^{2}$

El milagro santiaguista de los Votos y/o la invocación apostólica contra el islam pronto se difundió sobremanera, y en los siglos XIII y XIV experimentó un definitivo impulso, referenciándose en el Cantar de mio Cid, ca.1200; en el Chronicon Mundi de Lucas de Tuy, de 1236; en De rebus Hispaniae de Rodrigo Jiménez de Rada solo siete años después; en la Primera Crónica General y en las Cantigas de Santa María, de Alfonso X el Sabio; y en romanceros y cantares de gesta tanto en prosa latina como vernácula, caso de la Vida de San Millán de Gonzalo de Berceo; además de en Juan Gil de Zamora, fray Diego de Valencia o Juan de Mena entre otros (Varela Jácome, 1965: 785-798. Castro, 1975: 350-352. Sicart Giménez, 1982: 24. Falque Rey, 2002: 573-577. Fernández Gallardo, 2005: 150-174). Llegadas las postrimerías del XV e inicios del XVI, el apóstol ya se había convertido en la devoción más sobresaliente de la monarquía castellana a excepción de la Virgen y su Hijo, contribuyendo a ello la reina Isabel o el Cardenal Cisneros. Los propios Reyes Católicos incorporaron a la Corona en $1493 \mathrm{el}$ maestrazgo de la prestigiosa Orden de Santiago, hecho que, tras ser sancionado en 1523 por el papa Alejandro VI, convertía al monarca en el maestre mayor de la misma. Santiago, bajo su advocación caballeresca, suponía desde tres siglos atrás el Marte cristiano de las huestes hispanas; el bélico y santo intercesor a quien se encomendaban, incluyendo en sus arengas los gritos de "iSantiago!» o «iSantiago, y cierra España!» previa la embestida al enemigo. De hecho, su sobrenatural aparición sobre el albo corcel no se redujo solo a las batallas de Clavijo o Coimbra, sino que se repitió en la de Simancas o en la de las Navas de Tolosa entre otras. Todavía en la primera mitad del siglo XVI se adujo su presencia en las contiendas libradas en la América recién descubierta, y lo mismo en el XVII en Italia, Francia o el Norte de África (Ribadeneira, 1624: 474-475. Contreras y López de Ayala, 1971: 492, 494. Mon-

2. La ensoñación ramiriana retrotrae a la del emperador Constantino previa la Batalla del Puente Milvio contra Magencio (Réau, 1998: 170). Asimismo, existen concomitancias entre la historia de Clavijo y algún versículo bíblico, de ahí que la historiografía lo haya ligado con el apocalíptico jinete a caballo blanco (Ap 19,1 1-16); y también en menor medida con las huestes de Macabeo, a quienes favoreció Dios en pleno combate con la aparición celestial de unos caballeros que le brindaron el triunfo (2 Mac 10,28-30. Precedo Lafuente, 2008: 523). 
terroso Montero, 1997: 486. Cabrillana Ciézar, 1999: 107-114. Cardaillac, 2001: 109-131. Gómez López, 2004: 89-90. Márquez Villanueva, 2004: 284. Linares, 2008: 139-144 y ss. Olivera Serrano, 2013: 13-25. Olivares Torres, 2015: 368-381). ${ }^{3}$ En el quinientos la Corona se erigió -con la aprobación papal- en el ariete católico evangelizador de medio mundo, de ahí que rogara a su paladín Santiago ante todo cuanto enemigo impedía su Cruzada mesiánica, fuesen moriscos, musulmanes del Norte de África, turcos, protestantes, o naturales de las Indias, lo que llevó, dados los prósperos resultados, a enriquecer el predicamento del culto jacobeo (Steppe, 1985: 144. Saavedra Fernández, 1999: 131. Cardaillac, 2001: 129. García Morales, Nieto Alcaide, 2004: 34-35, 40-41. Monterroso Montero, 2004: 58; Gómez López, 2004: 87-88). Bien lo reseñaba entonces el jesuita Pedro de Ribadeneira al indicar que «con el amparo y proteccion deste glorioso Apostol, los mismos Españoles han lleuado por todo el mundo el estandarte de la Cruz, y plantado en las Indias, y en otras Prouincias y Reynos la dotrina Euangelica, y descubierto a las gentes ciegas los resplandores de la diuina luz" (Ribadeneira, 1624: 471). Y es que la "presencia del apóstol luchando junto con las tropas reales era una cierta confirmación divina de los altos fines de la política real, la defensa de la fe y de la cristiandad; en definitiva, el mito suponía la existencia de un vínculo especial de los reyes hispanos con Dios, origen y fuente de todo poder" (López López, 2008: 49). Dicho mito se fraguó en buena medida "gracias al gusto artístico y la mentalidad de los círculos cortesanos", impulsores de la tradicional vinculación de Santiago para con la monarquía (Gómez López, 2004: 89). De ahí que la Corona obviase por una vez los recientes preceptos tridentinos, y lejos de expurgar todo lo fantástico y legendario que envolvía a la figura de su santo patrón, abogase por la enraizada tradición del «hispanorum protectorum», difundida iconográfica y cultualmente por la Orden de Santiago desde tiempo atrás (Pita Andrade, 1971: 432. Monterroso Montero, 1997: 500. Ídem, 2004: 58-59. Cabrillana Ciézar, 1999: 30. Portela Sandoval, 2004: 73-74). En el siglo XVI esta faceta guerrera también se acrecentó sobremanera gracias a la alta consideración que experimentaron los ideales caballerescos, revestidos ahora de cualidades morales humanistas (Gómez López, 2004: 8889). Desde el último tercio de este siglo y durante los primeros decenios del XVII, enardeció una fortísima polémica sobre el hecho jacobeo que provocó una enconada revisión historiográfica del mismo. Personajes como el cardenal César Baronio o el eclesiástico García Loaysa y Girón, suscitaron dudas acerca de la venida del apóstol a Hispania. También las sembraron en torno al quebradizo corpus documental que verificaba su mítica aparición en Clavijo, y, consecuentemente, hacia su afán intercesor por la patria y la fe católica. Este escepticismo tuvo pronta contestación en obras como la Crónica General de España de Ambrosio de Morales, o en la Historia General de España del jesuita Juan de Mariana, así como en cantidad de monografías apologéticas de Santiago, entre las que descuellan la de Mauro Castellá Ferrer, editada en 1610, o la del dominico fray Hernando de Ojea, publicada dos años después. Para entonces, en estas grietas abiertas hacia la figura de Santiago ya había hendido el Carmelo, exultante por hacer de la beatificada Teresa la patrona estatal (Rey Castelao, 1985: 31-146. Ídem, 2006: 77-86. Linares, 2007: 521-542).

Conocidas las fuentes literarias que originaron la figuración ecuestre de Santiago y su evolución cultual, toca ahora analizar las gráficas. Básicamente su imagen marcial sustancia de manera fidedigna la descripción que de él se da en los textos citados. Por tanto, lo veremos ataviado como apóstol o como un verdadero caballero sobre un níveo corcel; blandien-

3. Respecto al grito de guerra « ¿Santiago!», indicar que la oración «dar un Santiago» -hoy en desuso-, significaba precisamente atacar al enemigo al son de dicho grito (Yzquierdo Perrín, 2005: 119). Sobre dicho grito véase (Linares, 2012).

IMAGO, NÚM. I0, 2018, 143-173 
do espada; algunas veces irguiendo el pendón; y en una sola portando escudo, elemento que no le atribuyen los escritos. Aparece con tal arma en un folio miniado de la ejecutoria de hidalguía de Fernando Barnuevo Anaya, de 1604 (Sánchez y Pineda, 1936: 62-63). ${ }^{4}$ Resulta además muy llamativo porque adquiere el formato de una concha descomunal. Por lo demás, bajo la montura suelen hallarse los enemigos tendidos. En ocasiones se omiten sus cuerpos, pero no las armas desperdigadas por el campo de batalla. Este tipo iconográfico, que en última instancia es deudor de las figuras de la Antigüedad grecorromana en las que el emperador a caballo pisotea al vencido (Sicart Giménez, 1982: 29. Olivares Torres, 2015: 47 y ss), siempre se ha considerado como una manifestación puramente hispana. Aquí nació, se desarrolló, y gozó de una significación intrínseca ajena a otros lares. El modelo hubo de surgir en la catedral compostelana, pues custodia los dos primeros ejemplos conocidos hasta la fecha: uno, en el llamado tímpano de Clavijo, de en torno a 1220; y otro, en una miniatura del Tumbo B, de 1326. Este último, a diferencia del anterior, tiene la particularidad de figurar al enemigo tendido bajo el caballo, o lo que es lo mismo, supone el primer Matamoros de que se tiene constancia. De todas formas, no resulta Santiago el pionero de los santos caballeros, pues le anteceden otros de procedencia oriental como san Teodoro, san Demetrio, san Mercurio, etc. (Sicart Giménez, 1978: 39. Ídem, 1981: 151. Ídem, 1982: 28-30. Herbers, 2006: 38). ${ }^{5}$ El Matamoros se expandió paulatinamente por la Península desde el siglo XIII. Primeramente por Galicia y demás tierras castellanas, y luego por el Sur. Apenas se ligó a la Reconquista mientras esta duró. Hubo que esperar a que concluyese para que su imagen se extrapolase a las luchas contra los turcos, los reformados europeos o los indios del Nuevo Mundo (Portela Sandoval, 2004: 74. Herbers, 2006: 97). En el resto de Europa tuvo escasa resonancia. Nula si la comparamos con su tipología apostólica o peregrina (García Morales, Nieto Alcaide, 2004: 35). Mientras que en la Sevilla de entre los siglos XVI y XVIII, alcanzó la más sobresaliente producción de cualquier otro punto de la Corona.

\section{LOS MATAMOROS DEL RENACIMIENTO SEVILLANO}

Entre 1531 y 1536 Alejo Fernández pintó las tablas del retablo de la Virgen de los Navegantes para la capilla de la Casa de la Contratación, sito actualmente en los Reales Alcázares. En él se encuentra el Santiago Matamoros pictórico de mayor antigüedad que conserva Sevilla [fig. 1]. El cuadro central figura a María en su advocación de la Misericordia amparando a personajes vinculados a la Carrera de Indias, entre los que se ha querido identificar, por citar algunos de los más señeros, a Carlos I o a Cristóbal Colón. Bajo ella se representa una parte de la Flota de Indias (Angulo Íñiguez, 1946: 24-25. Cabrillana Ciézar, 1999: 154). La flanquean en el lateral izquierdo san Sebastián y Santiago, mientras que en el opuesto san Telmo -entonces todavía beato- y san Juan Evangelista. El escenario en que se ubica el apóstol resulta inusual por tratarse de un entorno urbano. Viste capa roja y armadura completa con la salvedad de que el casco se sustituye por un sombrero aureolado. Enarbola en lo alto la espada y la bandera real de Ramiro I, evocadora de la Batalla de Clavijo. En el suelo yacen tres cabezas de moros decapitadas entre lanzas y un alfanje. ¿Por qué se ha-

4. La escasa frecuencia con que el apóstol se acompaña del escudo también la advierte Cabrillana (1999: 177).

5. Acerca de los santos caballeros a lo largo de la historia y su iconografía, se hace imprescindible consultar las siguientes tesis doctorales inéditas (Linares, 2008. Olivares Torres, 2015). 


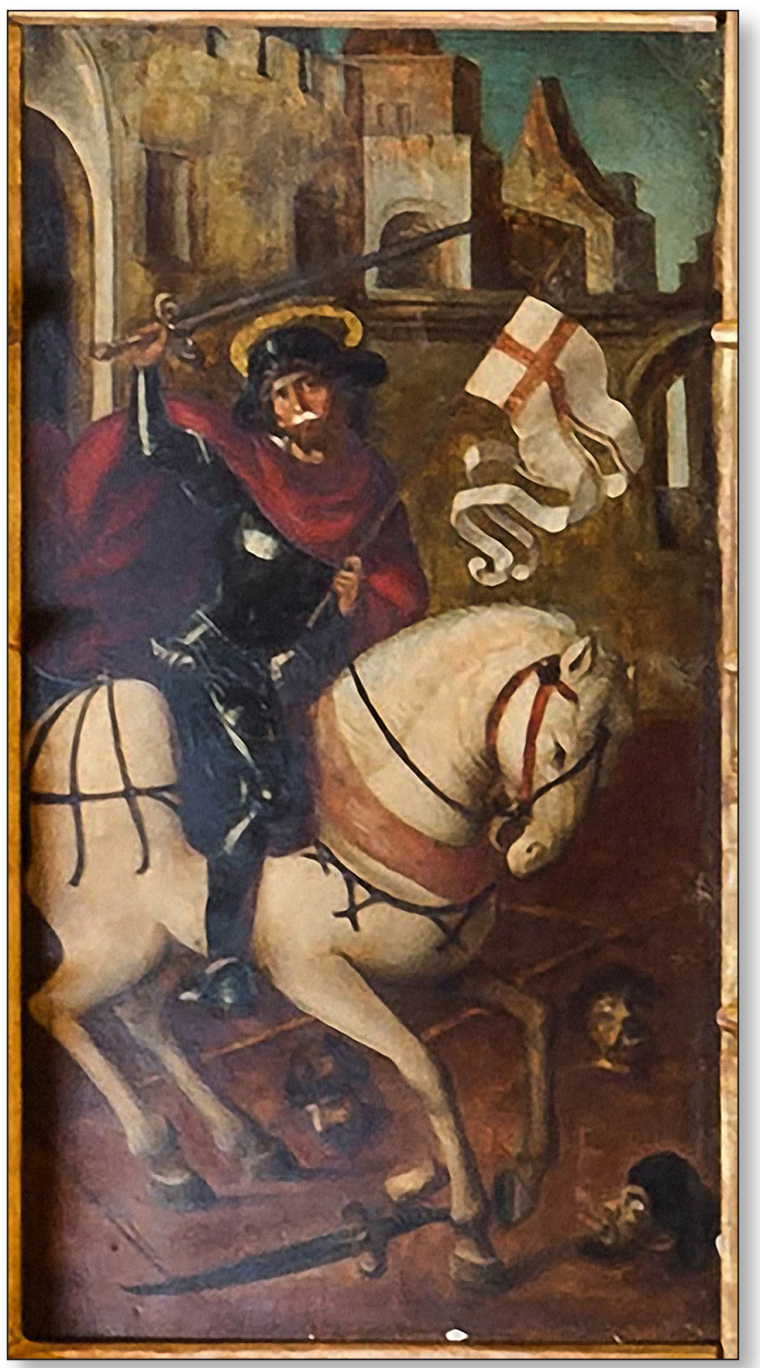

Fig. 1. Alejo Fernández, Santiago Matamoros. Sevilla, Reales Alcázares. bría de incluir a Santiago caballero en una obra como esta? Nicolás Cabrillana ha esgrimido con acierto una faceta del santo que la historiografía tiende a ignorar: su virtud como patrono de navegantes. Ya el Liber Sancti Iacobi, de mediados del XII, recoge tres milagros en los que intercede en la salvación de los marinos que lo invocan. Dos de estas intervenciones tienen su origen en las inclemencias del tiempo, mientras que la restante en un sarraceno que quiere hacer cautivos a los peregrinos embarcados hasta Jerusalén. Por todo ello y retomando parcialmente lo argumentado por dicho autor, creemos posible que los promotores de la obra lo incluyesen para que los protegiese de los múltiples peligros que el mar encerraba. Sus vidas y negocios, y por ende la prosperidad del comercio sevillano, dependían directamente de la bonanza climatológica y de no tropezarse con piratas a la vuelta del Nuevo Mundo. El santo ecuestre podría asimismo identificarlos como garantes del comercio local (Cabrillana Ciézar, 1999: 155. Moralejo Laso, 2004: 345 347, 349-350). ${ }^{6}$ En este sentido, hemos de tener en cuenta la manera en que se hubieron de avenir con el artista germano a la hora de concebir a san Sebastián, que aparece vestido como un rico caballero de la época y sujetando una espada, arma que le atañe por su condición de soldado romano,

lo que no impide que suponga una iconografía verdaderamente arcaica y desusada para las fechas en que nos movemos. Aparte de Santiago y de la propia Virgen, las referencias náuticas prosiguen en la tabla de san Juan en Patmos, en cuyo fondo paisajístico se vislumbran un par de naves; y cómo no, en la efigie de san Telmo, guardián de los marinos por antonomasia. Como dijimos, Sevilla todavía atesora una magnífica cantidad de imágenes del santo fromisteño, como también de Santiago, de san Nicolás de Bari o de san Juan Nepomuceno, todos ellos patronos de navegantes. Fiel reflejo, sin duda, de la devoción que les rindió en los siglos en que vivía fundamentalmente del comercio marítimo-fluvial.

6. Sobre los milagros marítimos del apóstol citados en el Liber Sancti Iacobi, consúltese a Díaz y Díaz (2004: 126128).

IMAGO, NÚM. 10, 2018, 143-173 
Un ejemplo correlativo en el tiempo lo supone el Santiago del retablo de la Purificación en la capilla catedralicia del Mariscal [fig. 2]. En 1553 el Cabildo le había concedido este recinto al mercader Diego Caballero para entierro suyo y de sus familiares. En su arreglo invirtió toda una fortuna, parte de la cual se destinó al retablo, ejecutado entre 1555 y 1556. De su ensamblaje se encargó Pedro de Becerril; de su policromía Antonio de Alfián; y de sus cuadros pictóricos Pedro de Campaña. En 1560 mudó de emplazamiento a la pared frontal en que hoy se halla (Gestoso y Pérez, 1890: 365-367. Ídem, 1908: 90-91, 279-283. Falcón Márquez, 1980: 51 52, 163-166. Serrera Contreras, 1984: 388. Otte, 2003: 333-334). Diego Caballero había sido el comerciante transatlántico más poderoso del reinado de Carlos I. Dedicó casi 50 años de su vida a distintos negocios, aunque fundamentalmente se ocupó del de las perlas en la isla de Santo Domingo -La Española-, en una compañía que regentó junto a su hermano Alonso. En 1535 abandonó la isla y al año siguiente le fue concedido el título de Mariscal de la misma, de ahí su sobrenombre. Ya instalado en Sevilla, ejerció como Veinticuatro (Gestoso y Pérez, 1890: 370. Serrera Contreras, 1984: 355, 357. Otte, 2003: 315-333). ¿Qué razones le movieron para solici-

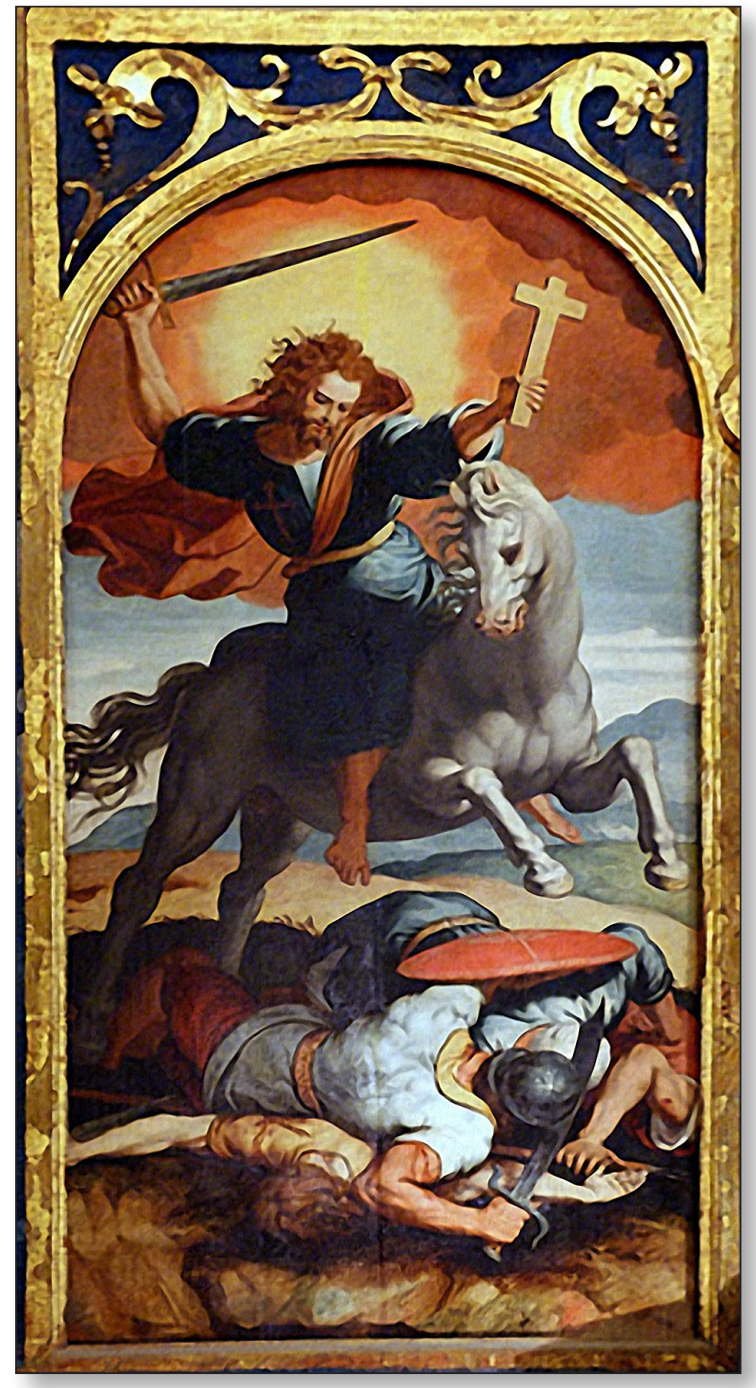

Fig. 2. Pedro de Campaña, Santiago a caballo. Sevilla, catedral, capilla del Mariscal. tar la pintura de Santiago en su reta-

blo privado? Pues quizá alguna de las siguientes. Mientras residió en América, hubo de saber de las campañas del ejército español, que atacaba al enemigo al grito de «iSantiago!», quien se aparecía en ocasiones para adjudicarle la victoria. Sus negocios dependían fundamentalmente del mar, salpicado de múltiples peligros como las inclemencias meteorológicas o la piratería, de ahí la posible inclusión del apóstol como guardián de navegantes. También pudo haber hecho un guiño a su familia política, ya que su suegro -y el de su hermano Alonso-, el comendador Pedro Díaz de León Garabito, era caballero de la Orden de Santiago. Ambos hermanos se habían desposado con sus hijas Leonor y Mencía, y se efigiaron los cuatro en el banco del retablo (Gestoso y Pérez, 1890: 370. Otte, 2003: 330). La última y quizá la más certera de las motivaciones, pudo devenir de que Santiago 
conformaba su santo patrono, pues se llamaba Diego. De igual forma, el patrono de su hermano era san Ildefonso, a quien precisamente se le pinta paralelo al apóstol, resultando sendos cuadros los de mayor tamaño y mejor situación dentro de las entrecalles del mueble (Angulo Íñiguez, 1951: 23. Valdivieso González, 2008: 111, 196, nota 123). En este sentido, sabemos de varios canónigos o caballeros sevillanos que tenían por nombre Diego y que para sus capillas privadas exigieron la figura de Santiago, llegando algunos a efigiarse junto a él. ${ }^{7}$

El idealizado miles Christi que aquí se nos presenta poco tiene que ver con el militar de la época concebido por Alejo Fernández. Respecto a este, carece de elementos veristas, luciendo apenas una ligera túnica y una capa que ondea al viento; yendo por lo demás descalzo, sin casco o sombrero alguno; y faltándole al caballo la silla, las bridas... Quizás exista una intencionalidad de expurgarle toda nota terrenal para dar idea de su celestial aparición, reforzada gracias al sobrecogedor celaje rojizo del que parece haber descendido el Hijo del Trueno, a quien el sol le sirve de nimbo no por casualidad. Ni siquiera sus adversarios se caracterizan como sarracenos, lo hacen más bien como guerreros a la romana y sin ningún afán cruento (Cabrillana Ciézar, 1999: 25, 158-159). De ahí que coincidamos plenamente con Diego Angulo cuando indica que no se encarna estrictamente al Matamoros, sino a un "caballero cristiano defensor de la fe» (Angulo Íñiguez, 1951: 23), que a tal fin, alza ostensiblemente la cruz y blande en lo alto la espada. Dichos objetos, a juicio de Cabrillana, evocan la etapa americana de los hermanos Caballero como colonizadores, puesto que simbolizan la misión evangelizadora y la conquista. Esta tesis la tomamos con cierta cautela, aunque sí reafirmamos una opinión suya acorde a la de Angulo, acerca de que el Santiago recuerda antes a un jinete extraído "de un friso griego o romano" que al "guerrero salido de Clavijo". Sin embargo, no nos sumamos a otra en la que señala como infrecuentes este tipo de representaciones tan idealizadas, pues existen innumerables ejemplos que demuestran lo contrario (Cabrillana Ciézar, 1999: 25, 158-161). En fin, Diego Caballero hubo de anhelar que el santo de su mayor devoción figurase junto a él en su recinto privado para que por medio de las misas allí dotadas intercediese por su alma para el logro del descanso eterno.

Pocos años después, se efectuaba por iniciativa del Cabildo el libro de la Fiesta de Santiago, intitulado In die Sancti Jacobi Apóstoli, hoy parcialmente recogido en el Libro de coro número 67. En su primer folio vuelto aparece la imagen ecuestre formando parte de la inicial miniada «A $»^{8}$ [fig. 3]. Nos consta que la pintó Diego Dorta entre 1561 y 1564, como también que el conjunto de la obra en cuanto a su escritura, iluminación, encuadernación y tafetán protector ascendió a un total de 58.391 maravedíes (Álvarez Márquez, 1992: 305. Marchena Hidalgo, 1998: 226-227, 240-241). Iconográficamente no presenta diferencias reseñables respecto al de Pedro de Campaña, si acaso la inclusión de algún elemento caballeresco como la cota de malla, la greba o la coraza en que se inscribe la cruz de la Orden.

7. Por citar solamente algunos ejemplos, en la catedral de Sevilla contamos con el altar de la Virgen del Consuelo, dotado hacia 1480 por el canónigo Diego López de Enciso; también con el sepulcro del arzobispo Diego López de Mendoza, hecho en 1509 por Domenico Fancelli; o con las pinturas del retablo de la Visitación, financiadas por el canónigo Diego de Bolaños en 1566. En la parroquial de San Andrés se conserva el Santiago contratado por el Veinticuatro Diego de Cabrera para su capilla en 1598. No ocurre lo mismo en la parroquial de San Lorenzo, pues se han perdido el par de 'Santiagos' y la santa Isabel que en 1623 habían contratado a Francisco Pacheco los patronos Diego López de Porras e Isabel de Montemayor para su recinto privado (Gómez Darriba, 2014: 75-76, $78,87,96)$.

8. Solamente lo hemos podido consultar a partir de su copia microfilmada (Institución Colombina, s.d.: fol. lv)

IMAGO, NÚM. 10, 2018, I43-I73 


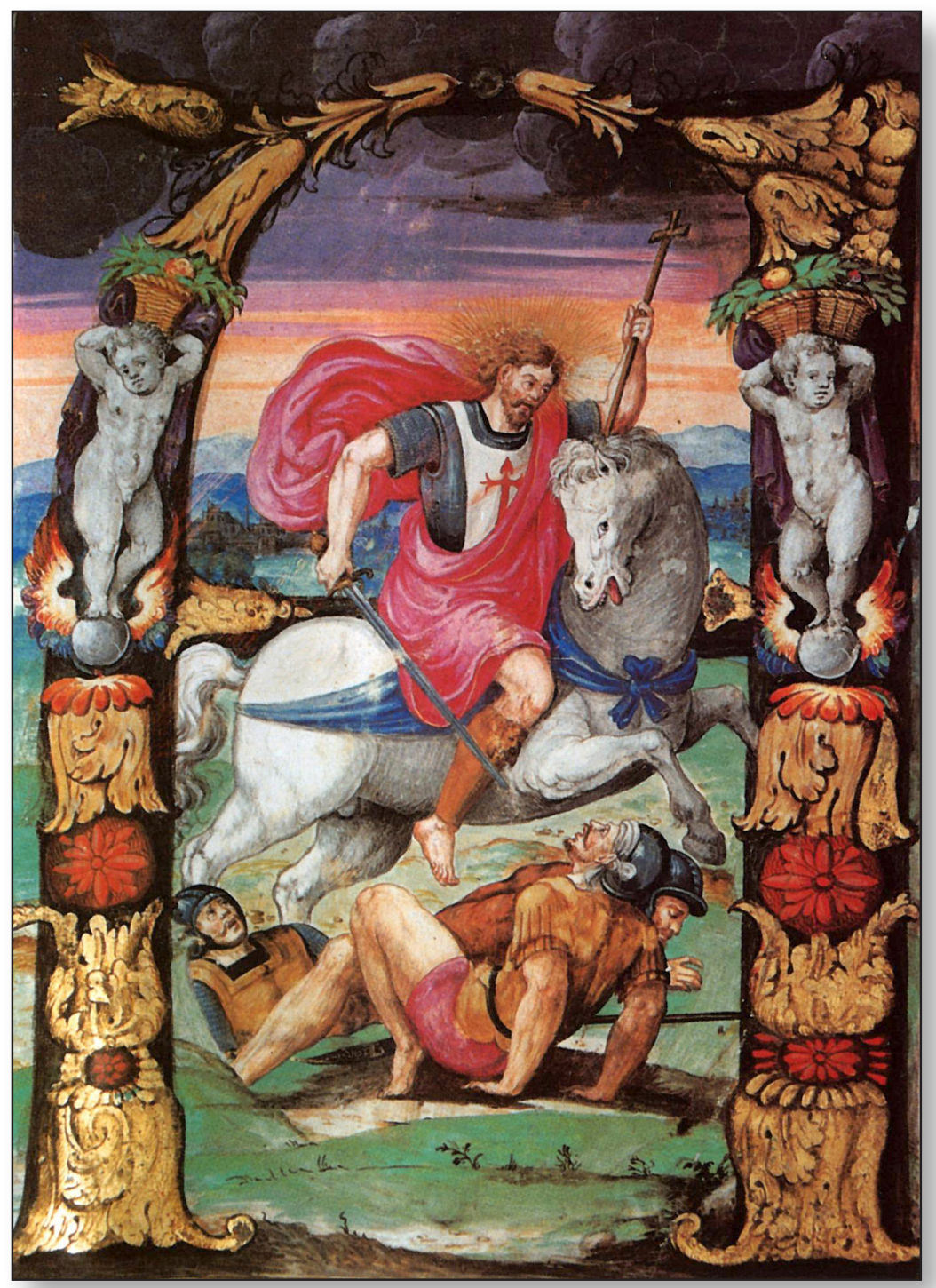

Fig. 3. Diego Dorta, Santiago Matamoros. Sevilla, Institución Colombina.

Por lo demás, se le vuelve a hacer portador de la cruz y la espada, si bien llama la atención cómo empuña esta para dar muerte al enemigo, detalle poco habitual puesto que lo común es que la enarbole sobre su cabeza. En este sentido, y a juicio personal, recuerda en cierta medida a un grabado de inicios del siglo XVI de Nicoletto da Modena en donde aparece un guerrero a caballo (Zucker, 1984: 133) [fig. 4]. Dicha estampa hubo de conocerse en la Sevilla de entonces, pues el Matamoros de la sacristía mayor de la catedral, realizado pocos años atrás, resulta casi un calco del mismo [fig. 5]. ${ }^{9}$

9. Acerca de dicha sacristía véase (Morales Martínez, 1984). 


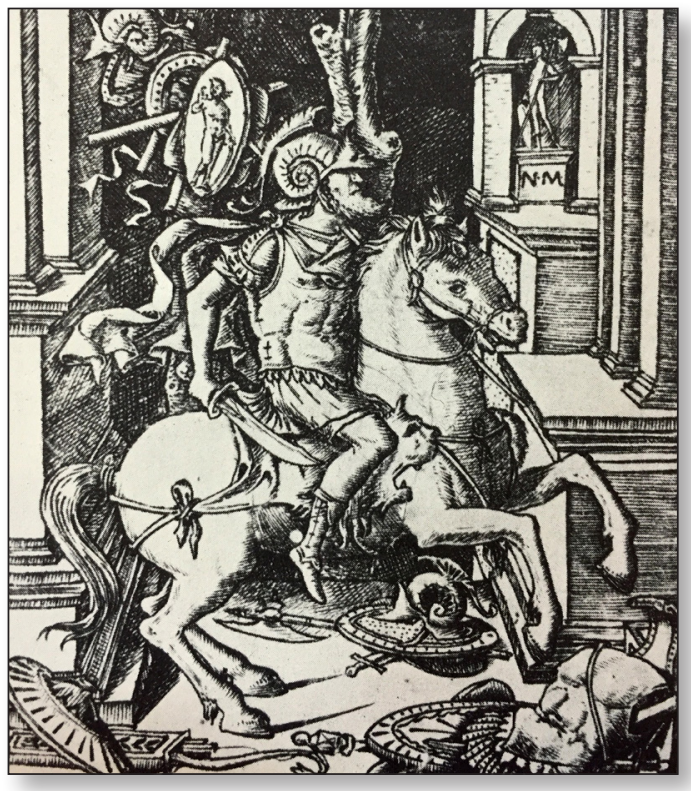

Fig. 4. Nicoletto da Modena, Guerrero romano.

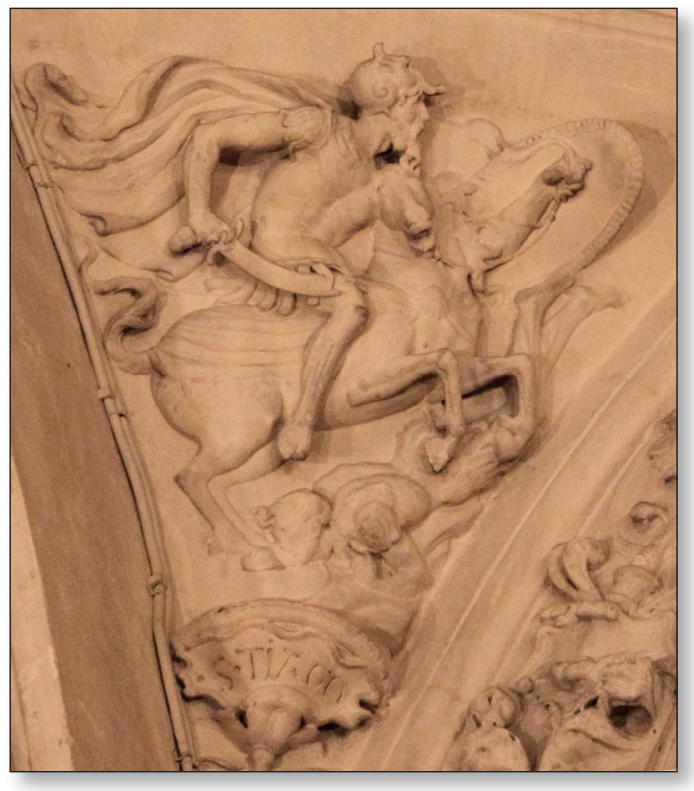

Fig. 5. Santiago Matamoros. Sevilla, catedral, Sacristía Mayor.

El motivo porque el cuerpo capitular hubo de precisar de este libro coral quizá radique en su interés por exaltar al santo que evangelizó, fundó, delimitó y reconquistó su archidiócesis, protegiéndola asimismo, como patrono de España que era, de los enemigos de la fe católica, tales como los piratas berberiscos, los moriscos, o los reformados europeos, que copaban buena parte de los problemas de la política interior y exterior del reinado de Felipe II. ${ }^{10}$ A la hora de lidiar contra todos ellos, nada mejor que encomendarse al paladín por antonomasia para con los intereses de la Corona: Santiago el Mayor.

Dentro de la miniatura local, entre esta segunda mitad del siglo XVI y primeros decenios del XVII, prodigaron más que nunca las ejecutorias de hidalguía, documentos emitidos por las chancillerías de Valladolid o Granada a petición de quien ambicionaba que se le reconociese su condición de hidalgo. Estas conformaban un soporte para la iluminación de distintos temas religiosos, y no por casualidad, el santo que cuantitativamente encabezaba esta lista era Santiago Matamoros. Sus demandantes exigían en ellas la inclusión de este tipo iconográfico para así probar que sus antepasados se habían enfrentado a los islamitas, y que por tanto, merecían ahora la condición de hijosdalgo. De hecho, en buena parte de las ocasiones, el apóstol comparte folio con el escudo de armas del solicitante como muestra de que supone el origen de su nobleza (Hidalgo Ogáyar, 1991: 343. Ruiz García, 2006: 251 -256, 272. Marchena Hidalgo, 201 1: 125, 132). Queda así comprobado, una vez más, que a la hora de ejemplificar la victoria de la fe católica frente a la herejía, nadie como Santiago.

10. Alguna de estas razones también las esgrime Rosario Marchena (1998: 242-243, 307. Ídem, 2005: 114-115).

IMAGO, NúM. 10, 2018, |43-173 


\section{AZULEJOS, ESTANDARTES, RETABLOS MAYORES Y DECENAS DE IMPRESOS A MAYOR GLORIA DEL PATRÓN DE ESPAÑA}

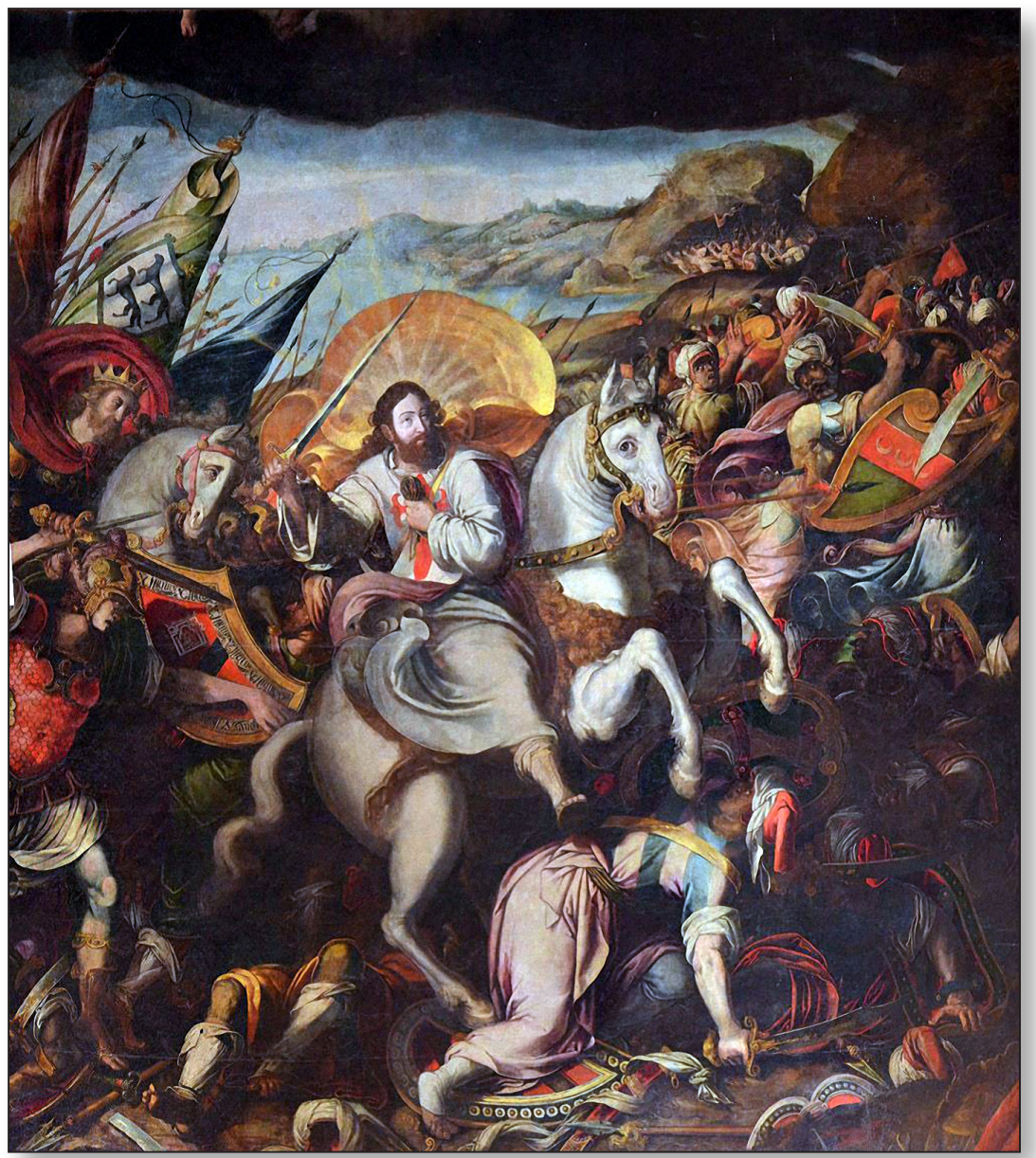

Fig. 6. Mateo Pérez de Alesio, Santiago Matamoros. Sevilla, iglesia parroquial de Santiago.

En la sevillana iglesia parroquial de Santiago el Viejo se conserva el primer gran cuadro de altar hecho en la ciudad, una tipología típicamente italiana importada en el último quindenio del XVI por el tardomanierista pullés Mateo Pérez de Alesio (Palomero Páramo, 1983: 295. Fernández López, 2002: 21. Valdivieso González, 2003: 104, 107). Esta obra la promovió Gonzalo Argote de Molina, un convencido santiaguista cuyo análisis biográfico nos esclarecerá por qué quiso exhibir al apóstol ecuestre de forma tan imponente [fig. 6]. Este célebre y polifacético personaje fue poseedor de varios señoríos y llegó a ocupar los cargos de Provincial de la Santa Hermandad y Veinticuatro. Aparte de su faceta militar, sobresalió como erudito historiador y genealogista; investigó en distintos archivos; escribió multitud 
de textos; y acopió un riquísimo fondo bibliográfico. ${ }^{11}$ También coleccionó tal cantidad de obras de arte, armas, animales exóticos y demás rarezas, que se dice que su particular gabinete habría despertado la curiosidad de Felipe II, quien lo habría visto de incógnito. Tenía Gonzalo unos 37 años cuando en 1585 el arzobispo Rodrigo de Castro le concedió para su entierro la capilla mayor de dicha iglesia de Santiago a cambio de 800 ducados. El primitivo templo había sido derribado en 1574, y del nuevo restaba el testero sin rematar. Gonzalo se comprometió a concluirlo, manifestando hacerlo «por la mucha devoción que yo tengo al señor Santiago" y "por una insigne victoria que tuve contra los moros». Pretendía exornarlo con el mobiliario y ajuar correspondientes, y disponer en él las sepulturas de sus antepasados, quienes también habían gozado del derecho de entierro en la capilla mayor de la pretérita iglesia. Entre los allí inhumados descollaba su bisabuelo Alonso de Argote, caballero de la Orden de Santiago caído frente a las armas agarenas. No era este el único predecesor de Gonzalo que heroicamente había combatido a los moros. En 1235 había sucumbido frente a ellos Martín Ruiz de Argote luego de haber participado en la conquista de la ciudad de Córdoba. De todos modos, Gonzalo retrotraía sus vínculos santiaguistas hasta la mismísima Batalla de Clavijo, pues admitía que los Villalobos, ascendientes suyos, habían concurrido a ella. Al igual que sus antecesores, en su periplo vital dio buenas muestras de su afán beligerante contra el enemigo islamita. En 1564, contando apenas 15 años, participó en la toma del Peñón de Vélez de la Gomera. Un lustro después lo hizo en la rebelión de las Alpujarras contra los moriscos, conflicto en el que consta la reiterada invocación al Hijo del Trueno y el grito de «iSantiago!» como sinónimo de ataque. Fenecido este episodio se alistó en el ejército de la Santa Liga para luchar contra los turcos. Luego combatió a los bandidos que poblaban la Serranía de Ronda, muchos de los cuales eran moriscos. Ya en 1586 partió hasta Lanzarote, donde contrajo matrimonio con la hija del primer Marqués de Lanzarote nada menos que un 25 de julio, festividad del martirio de Santiago. Su cónyuge, Constanza de Herrera y Rojas, fue secuestrada poco después por el corsario otomano Morato Arráez, pero Gonzalo logró rescatarla. Del conjunto de estos acontecimientos se sentía verdaderamente orgulloso, y pidió que constasen inscritos en el epitafio de su sepultura (López Martínez, 1921: 24, 38-50. Cotarelo Valledor, 1945: 225-228. Pepe Sarno, 1967: 166-167. Millares Carlo, Palma Chaguaceda, 1973: 19-36, 39-45, 220-236. Cabrillana Ciézar, 1999: 144-148, 150. Mármol Carvajal, 2015: 326, 422. Algarín González, 2015: 146-147, 150$151,159)$. Ante todo lo aducido queda claro que heredó de su familia una confesa devoción al apóstol, refrendada luego de asumirlo como santo protector en la cantidad de lides en que se vio envuelto. No es pues de extrañar, que el adorno de su capilla sepulcral tuviese al Matamoros como monumental protagonista.

Gonzalo representaba el ideal de caballero humanista del Renacimiento, dado que, como hemos visto, era un hombre de armas dispuesto a bregar en toda cuanta empresa bélica fuese menester, a la vez que un personaje instruido en artes y letras que había demostrado a lo largo de su vida altísimas inquietudes culturales de muy variado tipo. En 1584 contrató a Mateo Pérez de Alesio como pintor de cámara y le dio alojo en su propia morada. ${ }^{12}$ Tres años después el artista partió rumbo a Lima dejando el lienzo terminado (Millares Carlo, Palma Chaguaceda, 1973: 23. Bernales Ballesteros, 1973: 256). La idea primigenia radicaba en enmarcarlo en un retablo que inició Andrés de Ocampo en 1589, pero que se vio paralizado por la falta de liquidez y/o la muerte del promotor en 1596. Tres años después

11. Acerca de su biblioteca véase (Pepe Sarno, 1967: 165-262).

12. Sobre esta escritura de contrato consúltese (Algarín González, 2017: 627-642).

IMAGO, NÚM. 10, 20I8, I43-173 
la hermana de Gonzalo, Francisca Mexía, retomaba la empresa, y Vermondo Resta ideaba una nueva traza que rubricaba junto con Ocampo, quedando la obra terminada en 1600 (Palomero Páramo, 1983: 307-308). Aquí permaneció el cuadro hasta el siglo XX, en que se extrajo para disponer las imágenes titulares de las distintas hermandades que residieron en el templo. Hoy día se halla junto al coro alto. En todo este tiempo ha sufrido varias intervenciones pictóricas: una en 1631 llevada a cabo por Luis Ceballos; otra en 1726 debida a Juan Ruiz Soriano; otra cuando la reforma del retablo en 1789; y una última en 1985 por el profesor Francisco Arquillo (Gestoso y Pérez, 1892: 462. Bernales Ballesteros, 1973: 256. Palomero Páramo, 1983: 308. Porres Benavides, 2015: 801. Algarín González, 2015: 164-165). En esta se extrajo un metro de lienzo que el propio Ruiz Soriano había añadido a su parte baja en el siglo XVIII. En opinión de Ignacio Algarín este repinte se habría hecho para restituir el tamaño original de la tela, pues primitivamente era más amplia en su parte superior. Entonces Juan Ruiz hubo de optar por completar la escena del campo de batalla con una morisma caída -eliminada en 1985-, y no por reintegrar el posible rompimiento de Gloria que figuraría originalmente en el margen superior. Su hipótesis tiene mucho sentido y justifica la descontextualizada presencia de ese solitario pie pintado en lo alto (Algarín González, 2015: 165-167). A dicha tesis, nosotros sumamos la de que el rompimiento de Gloria pudo protagonizarlo un ángel guiando a las tropas hacia la victoria. Esta opinión la basamos en la posibilidad de que Mateo Pérez de Alesio conociese un grabado de Aliprandi Caprioli sobre composición de Paris Nogari que escasos años antes de la hechura del cuadro, en 1579, había publicado en Roma Lorenzo Vaccari. ${ }^{13}$ Las concomitancias compositivas entre esta impresión y la tela son evidentes [fig. 7]. En ambas escenas es casi idéntica la colocación de los distintos personajes y de las tropas huyendo en el segundo y tercer plano; lo mismo ocurre con la disposición de las lanzas y estandartes del flanco izquierdo; y no digamos con la línea de costa recortada ante una serranía que conforma el fondo paisajístico. Por todo ello, cobra mucho sentido que ese pie que hoy día apreciamos en el extremo superior del cuadro fuese un trasunto del

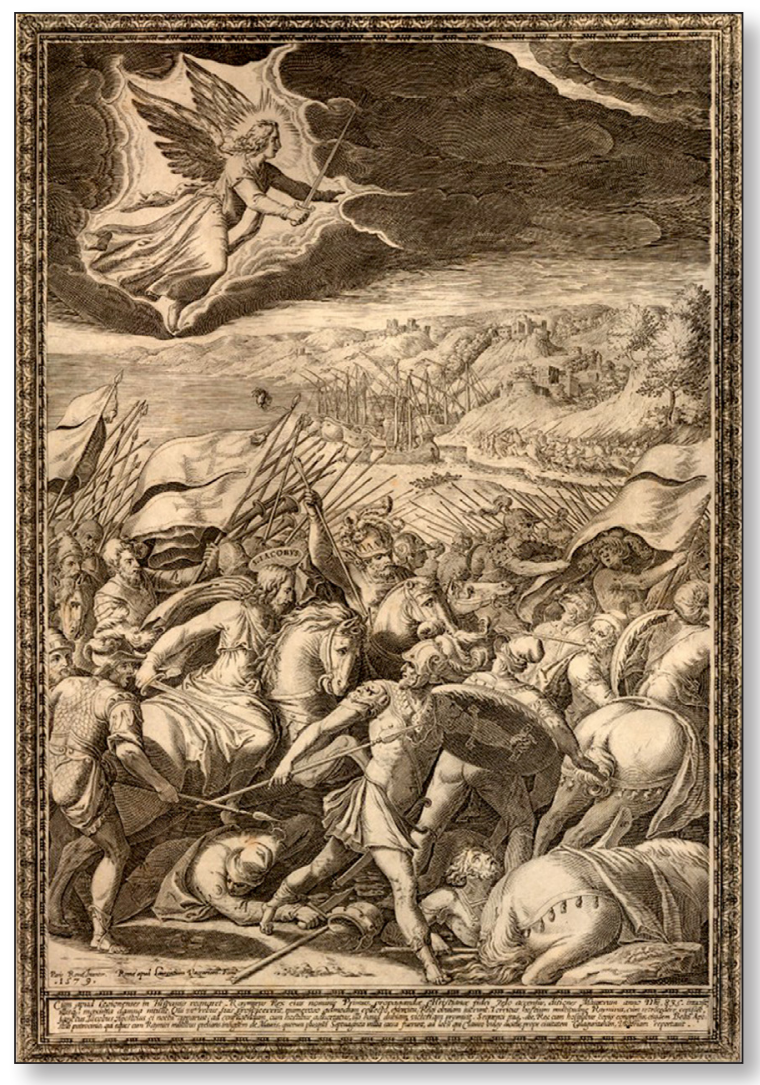

Fig. 7. Paris Nogari y Aliprandi Caprioli, Batalla de Clavijo. Grabado publicado por Lorenzo Vaccari en Roma en 1579.

13. Acerca de las fuentes grabadas en las que se basaron decenas de imágenes del apóstol en Sevilla véase (Gómez Darriba, 2017a). 
pie del ángel que se ve en la estampa, de hecho en ambas escenas coincide incluso la línea del celaje ennegrecido donde se encuadraría dicho personaje.

Sabiendo de la veneración que Gonzalo profesaba al apóstol, así como del cumplimiento del voto de realizar este Matamoros tras una victoria frente a los musulmanes, toca ahora llamar la atención sobre sus pretensiones en cuanto al modo de efigiar al santo y de componer la escena. En opinión de Cabrillana -aceptada por Algarín y sobre la que nosotros volvemos-, la figura de Santiago cabría interpretarla como una suerte de alter ego celestial del promotor, quien habría deseado para su capilla la imagen de su predilecta devoción luchando contra el enemigo que él mismo había enfrentado. Ello incluso ha llevado a suponer que la faz jacobea resulte un retrato criptográfico de Argote. Teoría que aunque en un principio pueda parecer descabellada, quizá no lo sea tanto dado que la fisionomía del rostro apostólico no difiere en demasía de la de los retratos que del noble se conservan, salvo que, como es obvio, cabellos y barbas luzcan más pobladas en el santo en concordancia con su codificada tipología facial. Uno de los citados retratos lo pintó Francisco Pacheco en 1599 con Argote ya difunto [fig. 8]. De todos modos se conocieron en vida, y a la hora de ejecutarlo hubo de inspirarse en otro análogo. El restante se debía a Matías de Arteaga y lo poseía el segundo Conde del Águila, también Provincial de la Santa Hermandad y caballero de la Orden de Santiago, pero de este únicamente resta un grabado y la descripción fisionómica que ante la obra original hizo Juan José López de Sedano en el siglo XVIII: «hombre de mediana estatura, no muy recio, aunque robusto de miembros, y el rostro abultado, la frente espaciosa, los ojos alegres y vivos, como ingenioso y esforzado; el aspecto agradable y majestuoso, el color blanco, la barba y cabello largo y bien puesto. Las virtudes de su ánimo correspondían a las que denotaba su aspecto, principalmente las del valor, la magnanimidad, la constancia y la piedad christiana» [fig. 9]. Además del semblante, la obra alberga ciertas particularidades que parecen aludir a Argote, algo lógico, dado que como promotor de la misma tenía derecho a exigir cuanto resultase de su agrado siempre y cuando se atuviese al debido decoro, y dado el asunto a componer, pudo aconsejar a Pérez de Alesio con la narración de sus vivencias bélicas frente a los islamitas. El intercambio de pareceres entre mecenas y artista hubo de ser más fructífero de lo habitual, dado que moraban bajo el mismo techo. Por poner un ejemplo, llama la atención la adarga del lado izquierdo, en la cual se escribe siete veces en grafía arábiga "no hay más vencedor que Alá», lema de 


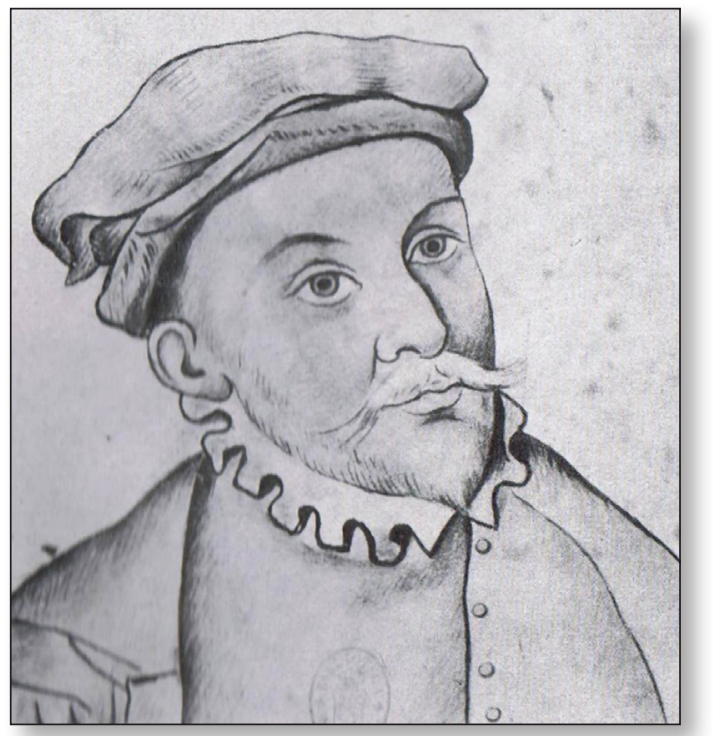

Fig. 9. Retrato de Argote de Molina. Grabado anónimo sobre composición atribuida a Matías de Arteaga. los sultanes nazaríes visible en multitud de monumentos granadinos. A la hora de pintar con tanto verismo estas letras, Pérez de Alesio pudo tener delante, sino un arma semejante -recordemos que su mecenas las coleccionaba-, sí al menos un texto en esta lengua, y precisamente Gonzalo guardaba varios en su biblioteca. Sorprende más todavía que la historia desarrollada tenga lugar no en un monte como el de Clavijo, sino en un paisaje marítimo próximo a una serranía. Con este insólito cambio de escenario quizá se quiso aludir a las calas sitas entre Fuengirola y Gibraltar de las que Argote salió victorioso de alguna batalla, pudiendo incluso tratarse del lugar en que obtuvo esa «insigne victoria [...] contra los moros" que le llevó a dotar la capilla (Millares Carlo, Palma Chaguaceda, 1973: 52-53, 227, 234. Cabrillana Ciézar, 1999: 25, 149-150, 152-153. Illán Martín, 2000: 123, 144. Algarín González, 2015: 143, 153-155, 157-158). Existe otra obra homónima en la que la línea de costa cercada por acantilados cobra también un palmario protagonismo. Se trata de una tabla pintada por Paolo de San Leocadio entre 1513 y 1518 para la iglesia de San Jaime en Villarreal, Castellón. A nuestro juicio, la playa y el mar que aquí sirven como escenario y telón de la contienda, puede que respondan a una nota localista en la que ambientar la intercesión apostólica, quizá con la pretensión de rogarle a este protector de navegantes la elusión del peligro turco en aguas levantinas. ${ }^{14}$ De todas formas, en la tela sevillana sí existe una evidente mención a la Batalla de Clavijo, aunque en paralelo a otra hacia el promotor. Hemos señalado que Gonzalo Argote de Molina entroncaba con el abolengo de los Villalobos, a quienes creía partícipes de la mítica contienda. Pues bien, en la bandera verde que se alza tras la figura del monarca, se inscriben los dos lobos pasantes propios del blasón de este linaje, también presentes en el escudo de armas de Gonzalo. Aparte de esto, él mismo reiteró en distintas ocasiones que tenía por santos de su mayor devoción además de Santiago, a san Fernando y a san Miguel, beligerantes ambos contra los moros. Recordemos que san Fernando les había arrebatado Sevilla entre otras muchas plazas, y su santidad se hallaba socialmente más que asumida pese a no estar canonizado por aquel entonces. En cuanto al arcángel, Argote creía en su contribución a la toma de Úbeda, y así lo reseñó en su célebre Nobleza del Andaluzia de 1588. Por ello Cabrillana ve posible que el rey Ramiro del lienzo pueda evocar a san Fernando, algo que Algarín afirma. También que el guerrero de la borgoñota empenachada se trate de san Miguel. Algarín lo ratifica trayendo a colación las innegables similitudes formales que existen entre este personaje y el arcángel que Pérez de Alesio había pintado para la Capilla Sixtina (López Martínez, 1921: 38-39. Cabrillana Ciézar, 1999: 151. Algarín González, 2015: 150-153, 158-159). A ello sumamos la posibilidad mencionada de que el lienzo original, en su parte superior, contase

14. Sobre esta pintura véase (Rodríguez Culebras, 1999: 180. Fernández Fuertes, 1999: 186). 
con un ángel sosteniendo una espada. En definitiva, el promotor querría a sus predilectas devociones efigiadas junto a su sepulcro. Así como habían enfrentado a los moros, habrían de interceder por su alma. El lienzo supondría un homenaje a Santiago, aunque aderezado con matices referenciales hacia el patrono de la capilla, que explicarían una parte cardinal de su biografía y de su ser. ${ }^{15}$

A lo largo del primer tercio del siglo XVII se levantó en España una inusitada polvareda en torno a la veracidad del hecho jacobeo a la que ya hemos hecho referencia. La Metropolitana Iglesia hispalense participó activamente en ella posicionándose a favor de la causa santiaguista, y lo ratificó mediante la publicación de impresos y la financiación de señeras obras artísticas que dieron ejemplo de su inamovible actitud. Bajo ningún concepto iba a permitir que se cuestionase al apóstol que había evangelizado, fundado, delimitado y reconquistado su archidiócesis. Como tampoco a quien seguía protegiendo el comercio marítimo de la ciudad, a las tropas españolas en sus luchas internacionales, y, en definitiva, a quien velaba por la prosperidad de España. Así, pasado un cuarto de siglo de la hechura del Matamoros de Pérez de Alesio, el Cabildo gestó otro grandioso cuadro de altar de idéntico tema en la catedral. ${ }^{16}$ Se hizo en 1609 para la capilla de Santiago, luego de que los canónigos dispusieran ornar esta y la de las Angustias con sendos retablos [fig. 10]. En septiembre del mismo debía tenerlo acabado el pintor y clérigo Juan de Roelas, quien hubo de recibir el finiquito en diciembre (Gestoso y Pérez, 1890: 539, 550-551. Mayer, 2010: 152). ¿Qué fines pudieron mover al Cabildo para idear una

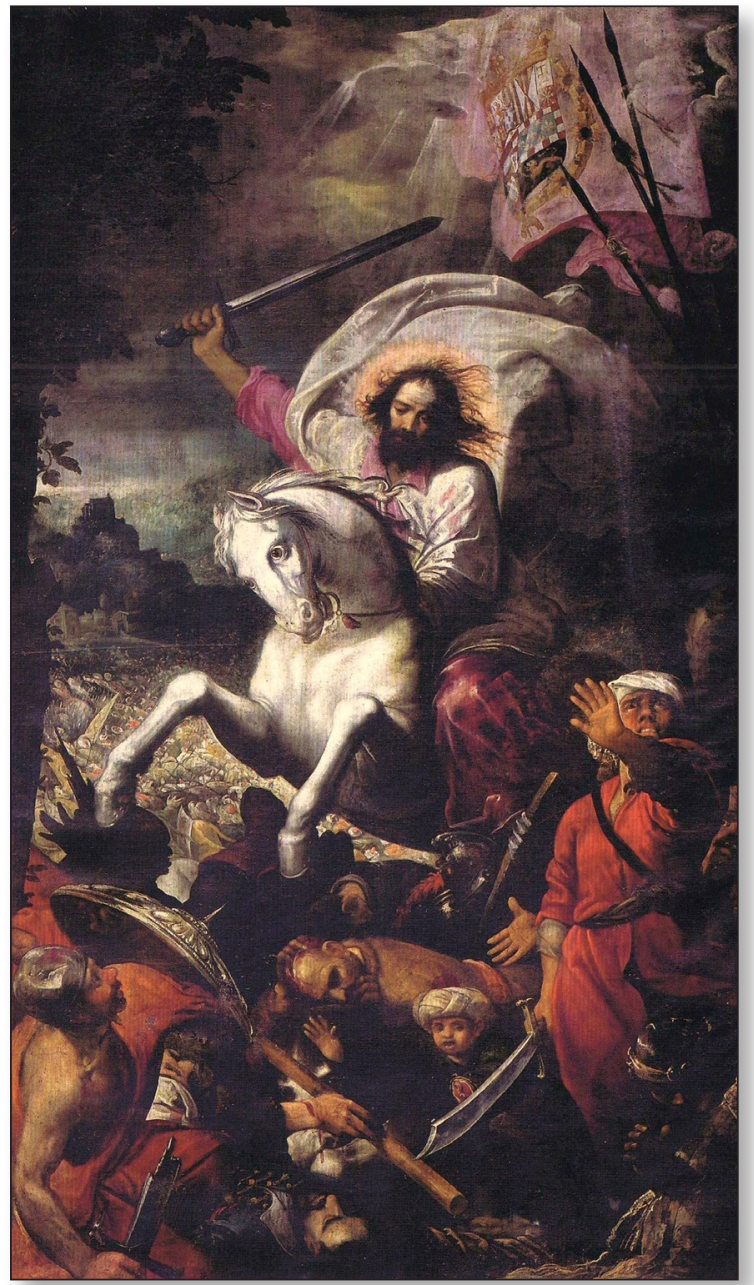

Fig. 10. Juan de Roelas, Santiago Matamoros. Sevilla, catedral, capilla de Santiago. obra de semejante magnitud con la imagen del apóstol en plena masacre sarracena? Compleja cuestión teniendo en cuenta que hasta la fecha carecemos de un corpus documental que arroje luz sobre el asunto. Pero buscando darle respuesta, llama la atención en el lienzo ese amplio estandarte en el que

15. Finalmente Gonzalo no pudo ver cumplido su deseo de inhumarse en el recinto, pues falleció en Las Palmas en 1596 y allí lo enterraron (Millares Carlo, Palma Chaguaceda, 1973: 27, 50, 220).

16. De 512 por $290 \mathrm{~cm}$ (Valdivieso González, 1978: 87). 
figura el escudo regio de Felipe III, sobre todo porque el cuadro lo costearon los capitulares. Su presencia aquí se justifica por ser Santiago el santo patrono de la Corona. Por ello, y a nuestro juicio, con esta obra se quiso invocar y homenajear al apóstol ante dos efemérides decretadas en abril de ese mismo 1609: la expulsión de los moriscos y la firma de la Tregua de los Doce Años con las Provincias Unidas de los Países Bajos, conocida también como Paz de Amberes. El propio capellán mayor y limosnero del rey, Diego de Guzmán, notificaba entonces que los reyes «hizieron sus votos y promesas [al apóstol Santiago], en razon de que este negocio tan importante de la expulsion y leua de los moriscos saliesse bien». ${ }^{17}$ El cuerpo capitular no debió encontrar mejor manera de secundar las áulicas imploraciones que patrocinando un monumental lienzo ofrendado al supremo defensor de la fe católica. ${ }^{18}$ De ser así, la invocación apostólica respondería una vez más a la llamada a las armas desde el Estado, tanto por el éxodo morisco, como por constituir el símbolo celebrativo de la paz lograda ante los holandeses tras decenios de continua lucha. Sea como fuere, reiteramos que la tela da buen ejemplo de la presencia jacobea al servicio de la propaganda política dentro de un conflicto bélico, toda una constante en época Moderna. ${ }^{19}$ Cabrillana se ha preocupado por la problemática que entraña el asunto, aduciendo a lo dicho un motivo que parcialmente guarda relación con los expuestos. Según él, el cuadro lo habría promovido el Cabildo en plena crisis religiosa y política para rememorar la tanta gloria que Santiago había concedido a España. De manera que nadie mejor que Juan de Roelas para sacar el máximo partido a dicho mensaje, pues aparte de ser el pintor insignia de la ciudad por aquel entonces, se le presuponían dotes casi innatas para mejor llevarlo a cabo. Primeramente por el hecho de ser eclesiástico, y por tanto, reflejar el tema de la manera más decorosa para con la sermonaria del momento; y luego por el arraigado patriotismo que poseería al ser hijo de Pedro de las Roelas, un caballero sevillano que junto con Gonzalo Argote de Molina había impulsado «la olvidada cofradía de San Hermenegildo para promover la cría caballar y los ejercicios de equitación" (Cabrillana Ciézar, 1999: 162-163). El lienzo se enmarcó en un retablo que el Cabildo acordó hacer en 1663 y que se atribuye a Bernardo Simón de Pineda (Ferrer Garrofé, 1982: 47). El mueble se halla guarnecido por entero de motivos militares, jacobeos y regios, en consonancia a lo expuesto en la tela. Así, los ángeles tenantes del cuerpo central exhiben los blasones castellanoleoneses y sujetan lanzas. Tras ellos aparecen haces de flechas, aljabas y yelmos. Los acompañan sus homólogos del ático mostrando adargas con medias lunas pintadas. En el entablamento se encastra una venera, y en la cúspide la cruz santiaguista. Bajo ella se encuentra un cuadro con el martirio de san Lorenzo que se atribuye a Juan Valdés Leal, lienzo que, según se ha dicho, pudo disponerse allí obedeciendo al interés particular de alguno de los canónigos (Valdivieso González, 1988: 134). Sea como fuere, su intrínseca temática liga decorosamente con el mensaje antiherético y promonárquico del conjunto de la obra, tanto porque el santo diácono prefirió la muerte antes que ofrecerse al paganismo, como porque se vinculaba devocionalmente a los Austrias desde tiempos de Felipe II, acordémonos sino de San Lorenzo de El Escorial.

17. Recogido textualmente de Julio Vázquez Castro (2014: 31). De hecho, quizá en acción de gracias, los reyes tuvieron la intención de peregrinar al santuario jacobeo de Compostela en el año jubilar de 1610. Finalmente no pudieron acudir por distintas razones, pero enviaron al mencionado Diego de Guzmán como delegado regio. Sobre este asunto consúltese la citada monografía de Vázquez Castro.

18. Motivo ya argumentado respecto a los moriscos en (Cabrillana Ciézar, 1999: 164-165. Péricard-Méa, 2011 : 69-71, 73). Su expulsión de Sevilla se verificó el 17 de enero de 1610 (Boeglin, 2011: 91-92).

19. Por citar otro claro ejemplo entre muchos, véase el sermón predicado en 1703 por fray Juan de Niela en Granada dentro del contexto de la Guerra de Sucesión (López López, 2008: 54-55). 
El Cabildo y el arzobispo de Sevilla se volvieron a manifestar como férreos defensores de Santiago pocos años después de haber encomendado el cuadro a Roelas. En 1617, el general de los carmelitas descalzos Luis de San Jerónimo, aprovechaba el filón de la reciente beatificación de Teresa de Cepeda y Ahumada para proponer a las Cortes de Castilla que la declarasen compatrona de España. Al año siguiente, el rey Felipe III -y no el papa Paulo V como indica Américo Castro-, le concedía tan subido rango, por lo que Teresa y Santiago pasaban a convertirse en patronos estatales ex aequo. Ello desató una guerra intelectual sin precedentes entre partidarios de una y de otro. La facción projacobea asumió la designación regia como un golpe más a la ya dañada figura del apóstol, cuestionada desde tiempo atrás en cuanto a la veracidad de su Praedicatio hispana y de su intercesión en la Reconquista (Castro, 1975: 391-397. Rey Castelao, 1985: 104. Ídem, 2007: 240-241. Ídem, 2015: 533$534,546)$. Pero lejos de enmudecer, se armó de plumas y prensas desde las que enaltecer a Santiago y desmerecer a Teresa. Entre otros, el arzobispo hispalense Pedro de Castro acaudilló parte de dicha militancia. Para ello, y de forma pionera, redactó un memorial y encargó otros textos en los que se criticaba el modo en que la abulense había sido llevada hasta el patronato, desacreditándola igualmente por considerar sus cualidades insuficientes para ocupar tan magna posición. La tenaz y beligerante postura de Pedro de Castro se justifica en que el menoscabo apostólico conllevaba el suyo propio. Desde los tiempos en que había ocupado la cátedra episcopal de Granada (1589 - 1610) se había convertido en el adalid del hallazgo de las reliquias y libros plúmbeos del Sacromonte, polémico desde su origen pese a interpretarse como un designio divino. El poner en tela de juicio la autenticidad de este descubrimiento y la evangelización de Santiago en el Sur hispánico, equivalía a deslegitimar por completo a las sedes arzobispales de Sevilla y Granada, pues con ello se negaba su fundación apostólica (Reyes Gómez, Santos Fernández, 2004: 26, 29, 243-254. Santos Fernández, 2008: 322-329, 341-342. Rey Castelao, 2015: 534), y por consiguiente, las sucesiones en la cátedra desde la antigüedad paleocristiana. En el caso hispalense desde el mártir san Pío, discípulo de Santiago; mientras que en el iliberitano desde san Cecilio, uno de los Varones Apostólicos que trajo sus restos hasta la Península. ${ }^{20}$

En el otoño de 1618 los procuradores de las Cortes de Castilla se retractaban de haber rebasado sus competencias a la hora de otorgar ritos a la beatificada Teresa, por lo que el rey decidía suspender las incoaciones pertinentes ante el papado. Pero apenas una década después, ya flamantemente canonizada desde 1622, su heredero Felipe IV y el valido de este, el conde-duque de Olivares, le devolvían el patronato, aprobándolo Urbano VIII sin perjuicio de que también lo ostentase Santiago (Castro, 1975: 391-397. Fernández Peón, 2008: 153-154. Rey Castelao, 2007: 243-244. Ídem, 2015: 534-537). Volver a igualarlos jerárquicamente no resultó plato de buen gusto para el bando projacobeo, que nuevamente desde púlpitos, manuscritos e imprentas, recrudeció la batalla intelectual, religiosa e histórico-política iniciada en 1618. Lo hizo con un mayor número de participantes y de modo más complejo. El principal instigador en esta ocasión fue el Cabildo compostelano, quien viendo peligrar los beneficios que a todos los niveles le suponía el patronato único de Santiago, acudió directamente a Roma sin la venia con el objeto de que se revocase el decreto papal, al tiempo que agitó a las sedes estrechamente vinculadas al hecho jacobeo -caso de la hispalense- para que contribuyesen a la causa (Cruz Valdovinos, 1999: 125, 135, nota 11. Márquez Villanueva, 2004: 341. Fernández Peón, 2008: 154. Rey Castelao, 2015: 537-539). El clero sevillano tomó el testigo de forma corporativa, y

20. Sobre los Varones Apostólicos consúltese (Castro Pérez, Prada Creo, Reboreda Morillo, 1995: 129-134). Acerca de la figura de Pedro de Castro, de la vinculación del apóstol Santiago con la sede arzobispal granadina, y de los libros plúmbeos, véase (Barrios Aguilera, 2004: 23 y ss. Ídem, García-Arenal, 2006. Barrios Aguilera, 201 1: 53 y ss).

IMAGO, NÚM. 10, 20I8, I43-173 
bien por encargo, bien motu proprio, no le tembló el pulso a la hora de verter tinta para hacer apología apostólica y menosprecio teresiano. Así, Martín de Anaya Maldonado, canónigo del convento de Santiago de la Espada, emitía a inicios de 1628 un texto projacobeo. El canónigo doctoral Francisco de Melgar, que ya en 1618 se había postulado abiertamente santiaguista, hacía lo propio entonces a petición del Cabildo sevillano. Ese mismo 25 de julio, coincidiendo con la festividad del martirio de Santiago, el catedrático Hernando Cano de Montoro pronunciaba en la catedral unos discursos en presencia del arzobispo Diego de Guzmán y Haro. Estos se imprimieron días después, y aún en 1638 veían la luz otros del mismo autor (Cano de Montoro, 1628. Melgar, 1628. Maravall, 1975: 274. Rey Castelao, 1985: 105-106. Ídem, 2015: 538. Reyes Gómez, Santos Fernández, 2004: 67, 83, 122, 134-135, 163-165, 431432. Santos Fernández, 2008: 338). De la suma de los impresos citados merece destacarse la portada de la obra de Francisco de Melgar por el grabado que presenta, de autoría desconocida (Garrido Moreno, 1976: 143, 194) [fig. 11]. Lo preside la figura de Santiago ecuestre sobre las cabezas y demás miembros esparcidos de los moros, cuyas tropas enfilan la retirada haciendo visible un gonfalón con la media luna. Parece que el mensaje aquí manifestado no es otro que el triunfo de la fe católica frente a la herejía islamita. De ahí la gloriosa

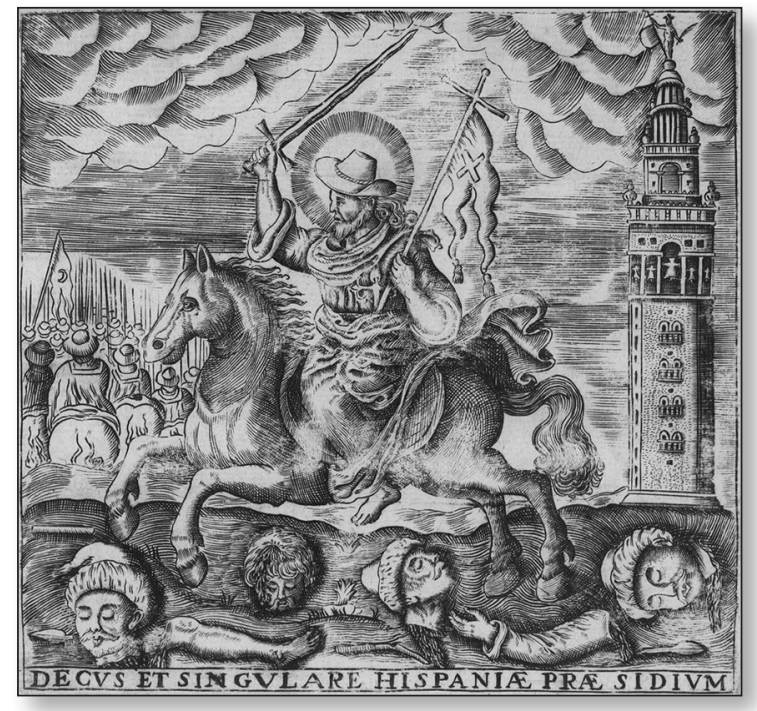

Fig. 11. Portada de Proposicion, y Discurso sobre si deve ser admitida por Patrona... de Francisco de Melgar. aparición del apóstol sustentando un pendón con la cruz junto a la Giralda, antiguo alminar luego cristianizado como torre campanario, coronada a su vez por el Giraldillo, símbolo del «Triunfo de la Yglesia» y de la «Fe Victoriosa" a decir del Cabildo contemporáneo a su realización en 1568 (Aguayo Cobo, 1999: 228). ${ }^{21}$ El rótulo del grabado recalca su alto cometido como protector de España: «Decus et singulare Hispaniae praesidium», e igualmente existe una referencia a su papel como evangelizador, fundador, reconquistador y defensor de la archidiócesis, inherente a los elementos que conforman la estampa.

Finalmente, en 1629 se restauró el patronato único, y la controversia quedó zanjada luego de que Urbano VIII promulgase el 21 de febrero de 1630 el breve que ratificaba al mayor de los Zebedeo en tan superlativa posición (González López, 1969: 346. Rey Castelao, 2015: 539). No tardó el Cabildo hispalense en celebrar esta sanción, y para ello organizó unos festejos con que compartir públicamente su gozo. Así, hizo que la Giralda amaneciese el sábado 17 de mayo «entre vanderas, y gallardetes repartidos a trechos en medio dellos, un estandarte de damasco carmesí, de grandeza, conforme al sitio, donde por su altura se

\footnotetext{
21. Aguayo hace hincapié en la hibridación iconográfica de la célebre veleta. En su opinión entremezcla atributos característicos de la Fe, la Fortuna y la Victoria, para declarar el triunfo del catolicismo sobre la herejía, y aludir también al venturoso viento que conduce a los barcos rumbo a Indias con el propósito de evangelizar a sus naturales (1999: 234-235. Ídem, 2013: 98, 110-111).
} 
reparò, en que devia tenerla para ser bien visto, pintada en el una imagen del glorioso Apostol, en un cavallo blanco, con espada en la mano, qual se nos representa en las apariciones que le dibuxan las historias, traslado de aquellos originales, y asombro de los enemigos de la Iglesia». Junto al santo se hallaban las armas reales "que deven ponerle, para lograrlas en las ocasiones que se aventuran, al amparo del Apostol, su cierto, y mayor seguro». A las doce del mediodía repicaron las campanas de las iglesias de la ciudad, y por la noche se encendieron luminarias en la torre. El domingo se ofició una misa solemne en la catedral a la que asistió lo más granado de la sociedad civil, religiosa y militar del momento, y se llevó a cabo una procesión por el interior del templo con estación en la capilla de Santiago, exornada para tan singular ocasión. Previa la conclusión de la ceremonia sonó la música del órgano, de los ministriles, nuevamente las campanas y también las salvas desde los navíos atracados en el Guadalquivir. ${ }^{22}$ Este enorme estandarte que exhibía a Santiago como único patrón de España junto al escudo real constituyó un formidable ejemplo de arte efímero. Su iconografía de Matamoros casó a la perfección con la Giralda, dando buen ejemplo, torre y santo, del triunfo de la fe verdadera sobre «los enemigos de la Iglesia» -como reza el texto-. Suspendido en sus 100 metros, y dada la orografía local, se puede decir que el apóstol, sin menoscabo del Giraldillo, presidió durante unos días el cielo y horizonte de Sevilla. Por desgracia este estandarte no ha llegado hasta nosotros, pero sí se conservan otros cuya tipología e iconografía se asemejan a su descripción. Uno de excepcional valía lo custodia el Museo Naval de Madrid, y precisamente se atribuye al pintor sevillano Francisco Meneses Osorio (Pita Andrade, 1971: 588), tenido por el mejor discípulo de Murillo (Serra Giráldez, 1990). Se trata del repostero de la Casa Ducal de Fernán Núñez, en el que el Matamoros y la Inmaculada flanquean al Crucificado dispuesto sobre las armas reales [fig. 12]. Sea o no obra de Meneses, cabe llamar la atención acerca de la oración del impreso que expresa que al apóstol se le figura «qual se nos representa en las apariciones que le dibuxan las historias, traslado de aquellos originales», para añadir que las similitudes compositivas entre esta imagen ecuestre y la conocida de Pedro de Campaña resultan evidentes.

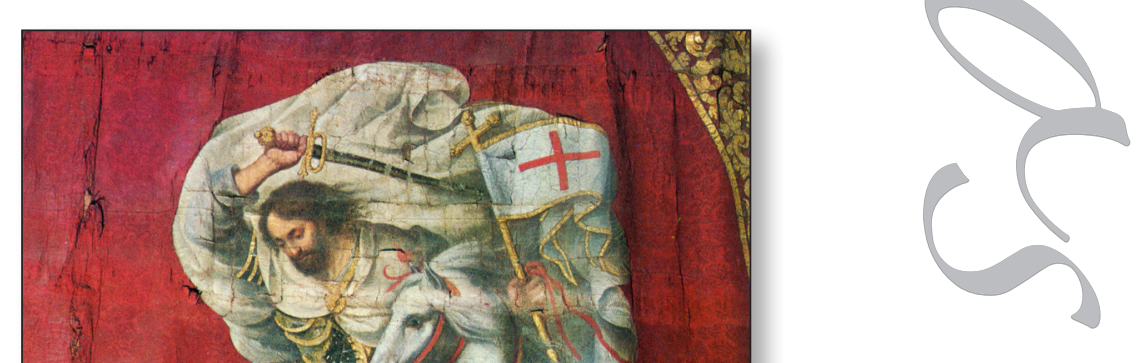

22. El impreso del que recogemos estos datos se custodia en la (Biblioteca General de la Universidad de Sevilla, s.d.: s.p.). Existe otro acerca de estos festejos. Lo citan (Reyes Gómez, Santos Fernández, 2004: 127).

IMAGO, NÚM. 10, 2018, 143-173 
La disposición del corcel y del apóstol se antoja casi calcada. Se reitera también la cabeza destapada y los pies descalzos. No obstante, a la indumentaria clásica se le incorpora una armadura con hombrera, peto y escarcela. Con la mano derecha hace gravitar la espada sobre su cabeza, dispuesto a asestarla a la morisma entregada bajo las patas del equino; mientras que con la izquierda ase una cruz de la que pende el gonfalón. Lleva el apóstol la vestimenta que la Regla de la Orden de Santiago establecía a sus caballeros: el coselete o armadura que protege tronco y brazos; la capa blanca con la cruz bordada que todo caballero vestía no solo en los combates sino también en ceremonias solemnes y capítulos; y la bandera con la cruz que únicamente portaba la alta jerarquía de la entidad, símbolo del triunfo de Cristo sobre los enemigos de la fe (Cabrillana Ciézar, 1999: 28-29, 49-50).

La genealogía de cuadros de altar dedicados al Matamoros siguió aumentando en la ciudad de Sevilla, y veinticinco años después del de Roelas, se realizaba otro para el retablo mayor del templo de Santiago de la Espada, hoy convento mercedario de la Asunción. Desgraciadamente se desconoce su paradero, pero los eruditos dieciochescos y decimonónicos que lo vieron, tales como Ortiz de Zúñiga, Arana de Varflora, Ponz, Ceán o González de León, confirmaron que mostraba al apóstol en Clavijo, verificándolo Celestino López al hallar su contrato de ejecución. Fue concertado el 19 de abril de 1635 entre el prior Pedro González Gragera y el pintor Francisco Varela, luego de que el dibujo preparatorio del artista recibiese el visto bueno del licenciado Martín de Anaya Maldonado, el mismo canónigo del convento que en 1628 había redactado uno de los textos projacobeos a los que ya hemos hecho alusión. Dicho clérigo se habría ocupado de tal cometido porque sería de entre los suyos el mejor instruido en decoro e iconografía. Varela se comprometió a pintar al «señor sanctiago patron de españa dando ayuda a los christianos contra los moros» en tres meses y a cambio de 2.800 reales, plazo que nos lleva a pensar en el posible interés de la Orden por tenerlo a punto para la festividad del 25 de julio. No creo casual que en este preciso convento se contratase un lienzo con semejante temática justo un mes después de que Francia le hubiese declarado la guerra a España, que concluiría en 1659 con la Paz de los Pirineos. A juicio personal, cabe la posibilidad de que el estallido del conflicto fuese el detonante o al menos una de las motivaciones para su pronta hechura. Sea como fuere, desde luego no existía iconografía más idónea con que rogar la consecución de la concordia al santo patrono y guardián de las Españas. En 1810 los franceses lo llevaron al Alcázar, en cuyo inventario constan dos cuadros del Matamoros debidos a Varela. Ha de identificarse con el registrado con el número 393, dado que sus dimensiones coinciden con las manuscritas en el contrato de obra. Rondaría pues los 600 por $300 \mathrm{~cm}$, tamaño equiparable al pintando por Roelas en la catedral. Luego retornó al convento y José María Arango lo restauró antes de la exclaustración del mismo, tras la cual pasó a formar parte de la colección del Museo de Bellas Artes local. Pero en fecha incierta se le perdió la pista y nada se ha vuelto a saber de él (Gómez Imaz, 1917: 175-176. López Martínez, 1928: 205. Serrera Contreras, Valdivieso González, 1985: 254-255. Fernández Rojas, 2005-2006: 322). Igual suerte corrió otro de idéntico tema que los citados cronistas describen como de menor formato y dispuesto en el arco toral de dicha capilla mayor, asignándolo a Francisco de Herrera el Viejo. Según Félix González de León debió desaparecer durante la invasión francesa, aunque autores posteriores como Mayer lo señalan en su ubicación original (Mayer, 2010: 198. Martínez Ripoll, 1978: 204-205. Fernández Rojas, 2005-2006: 322). La sevillana iglesia parroquial de San Pedro alberga en la capilla del Pilar un Matamoros que, por tamaño -unos 300 por 200 cm- coincidiría con el otro 'Varela' incautado (Gómez Imaz, 1917: 175-176). Además, estilísticamente podría datarse hacia 1630 pese a advertirse un repinte posterior. De todos 
modos estas coincidencias no resultan suficientes para adscribir dicho cuadro al pintor. ${ }^{23}$ Del origen de la obra solo sabemos con certeza que responde a la donación de una feligresa a la Hermandad de María Santísima del Pilar y Santiago Apóstol. ${ }^{24}$ En la tela se figura al Hijo del Zebedeo de forma análoga que en el cuadro de Roelas. Con toda serenidad blande su espada de cazoleta en lo alto, dejando ondear una larga capa blanca con la cruz de la Orden, mientras que el fondo vuelve a reincidir en un paisaje rocoso y crepuscular.

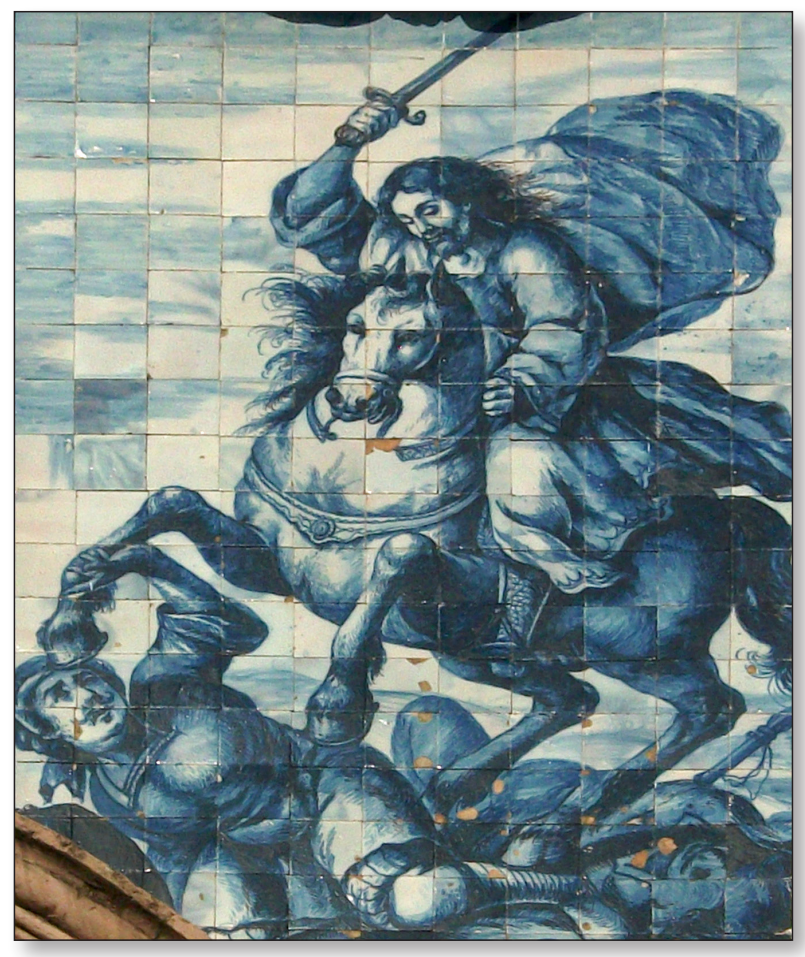

Fig. 13. José García, Santiago Matamoros. Sevilla, iglesia del Hospital de la Santa Caridad.

Un último Matamoros sevillano de gran significación se halla en la azulejería de la fachada del Hospital de la Caridad, haciendo pendant con san Jorge [fig. 13]. Esta obra, creída hasta hace poco del siglo XVII, fue realizada en 1733 por José García (Ramos Suárez, 2011: 496500). La presencia de san Jorge se explica por ser el titular del templo. La del apóstol podría deberse a varios motivos, como que un buen número de hermanos de la Caridad fuesen a la vez caballeros de Santiago, ${ }^{25}$ o porque en el año previo a la instalación de los azulejos la ciu-

23. Aparte de estos dos Matamoros de Francisco Varela, tengamos en cuenta que el ya aludido segundo Conde del Águila, tenía dentro de su rica colección pictórica dos cuadros de idéntica temática atribuidos a Herrera el Viejo, coetáneo de Varela, y al parecer dispuso uno de ellos en la capilla mayor de la sevillana iglesia de San Juan de la Palma (Illán Martín, 2000: 127-128, 145).

24. Tal y como me confirmaron miembros de la propia hermandad.

25. El propio hermano de Miguel de Mañara, Juan Antonio, había logrado entrar en esta restringida Orden tiempo atrás (Castrillo Utrilla, 1993: 290).

IMAGO, NÚM. 10, 20I8, I43-173 
dad había festejado los logros de las tropas españolas en la conquista de Orán, publicándose numerosos escritos que exaltaban esta victoria en territorio musulmán. En octubre de dicho 1732 el triunfo volvía a sonreír al ejército, en esta ocasión contra los moros ceutíes. No sería de extrañar pues, que la ubicación de Santiago guardase relación con estos hechos, como tampoco que su presencia contribuyese a la exaltación de la monarquía borbónica en un instante en el que precisamente los reyes residían en Sevilla, pues aquí se habían instalado en 1729 y no regresarían a Madrid hasta 1733, mismo año en que se colocó la imagen del apóstol (Ramos Suárez, 2011 : 503, 509-510). ${ }^{26}$ Sea como fuere, los cuatro santos que presiden la fachada tienen una clara vinculación regia: arriba los azulejos de san Jorge, patrono por antonomasia de la Corona de Aragón; a su lado Santiago, patrono de la de Castilla y/o "de las Españas»; y abajo las esculturas de san Luis, rey de Francia; y de san Fernando, rey de Castilla y León y patrono a su vez de Sevilla.

\section{CONCLUSIÓN}

Hemos podido ver un riquísimo conjunto de lienzos, tablas, estandartes, azulejos, folios iluminados, e impresos, que dan buena muestra de la devoción que Santiago Matamoros despertó en la Sevilla de entre los siglos XVI y XVIII. Dichas obras reflejan que la ciudad entera se puso bajo su protección y amparo, invocándolo principalmente sus altas esferas: los arzobispos, el clero capitular y regular, la alta nobleza, o la pudiente burguesía, para que intercediese en las distintas cruzadas contra los enemigos de la fe católica, para que lo hiciese también por sus almas, y para que su tradicional patronazgo no se viese soslayado por quienes querían otorgar a santa Teresa la privilegiada posición de la que secularmente había gozado Santiago. En el arco temporal abarcado, ningún otro punto peninsular, americano o europeo, le tributó semejante veneración, como tampoco la materializó en tantas y tan señeras obras artísticas. De ahí nuestra afirmación de que la Sevilla moderna constituyó una capital mundial del culto y arte jacobeos.

\section{FUENTES}

Barrios Gutiérrez, M. [1989]. Querella del Apóstol Santiago y Suma de papeles liberales, Madrid, Tecnos.

Biblioteca General de la Universidad de Sevilla [s.d.]. Relacion de la Solemnidad con que en la Santa Iglesia de Sevilla, se publicò el breve de su Santidad, en favor del Patronato unico, y singular de España del glorioso Apostol Santiago.

Cano de Montoro, H. de [1628]. Al Ilustrissimo y Reverendissimo señor Don Diego de Guzman, Patriarcha, Arçobispo de Sevilla. El Dotor Don Hernando Cano de Montoro, Collegial Mayor, y Chatedratico de Durando, en su Universidad. Dedica y consagra estos Discursos, Predicados en su Sancta Yglesia, en defensa de el unico Patronato de nuestro grande Apostol Sanctiago el Mayor, hijo del Zebedeo, Sevilla, Juan de Cabrera.

26. La victoria en Orán se celebró en todas las ciudades del Reino (López López, 2007: 95). 
Espinosa de los Monteros, P. De [1627]. Primera parte, de la historia, antiguedades y grandezas, de la muy noble y muy leal Ciudad de Sevilla, Sevilla, Matias Clavijo.

Gestoso y Pérez, J. [1890]. Sevilla monumental y artística. Historia y descripción de todos los edificios notables, religiosos y civiles, que existen en esta ciudad y noticia de las preciosidades artísticas y arqueológicas que en ellos se conservan, Sevilla, Hispal, t. II.

Gestoso y Pérez, J. [1892]. Sevilla monumental y artística. Historia y descripción de todos los edificios notables, religiosos y civiles, que existen en esta ciudad y noticia de las preciosidades artísticas y arqueológicas que en ellos se conservan, Sevilla, Hispal, t. III.

Gestoso y Pérez, J. [1908]. Ensayo de un diccionario de los artífices que florecieron en Sevilla desde el siglo XIII al XVIII inclusive, Sevilla, Andalucía Moderna, t. III.

Gómez Imaz, M. [1917]. Inventario de los cuadros sustraídos por el Gobierno intruso en Sevilla (año 1810), Sevilla, M. Carmona.

Institución Colombina, Archivo Musical de la Santa Iglesia Catedral de Sevilla [s.d.]. Libro de coro $n .^{\circ} 67$.

López Martínez, C. [1921]. Algunos documentos para la biografía de Argote de Molina, Sevilla, Eulogio de las Heras.

López Martínez, C. [1928]. Arquitectos, Escultores y Pintores Vecinos de Sevilla, Sevilla, Rodríguez, Giménez y C. .

Mármol Carvajal, L. del, Castillo Fernández, J. (ed.) [2015]. Historia del rebelión y castigo de los moriscos del Reino de Granada, Granada, Universidad de Granada, Tres Fronteras, Diputación de Granada.

Melgar, F. DE [1628]. Proposicion, y Discurso sobre si deve ser admitida por Patrona General de España, juntamente con su antiguo y unico Patron Santiago, la Bienaventurada Santa Theresa de IESUS, conforme a lo determinado por los Procuradores de Cortes, y Breve de la Santidad de Urbano Octavo, Sevilla, Francisco de Lyra.

Moralejo Laso, A. y otros (trads.) [2004]. Liber Sancti Iacobi, Codex Calixtinus, Santiago de Compostela, Xunta de Galicia.

Ribadeneira, P. De [1624]. Primera parte del Flos Sanctorum o Libro de las Vidas de los Santos en la qual se contienen las vidas de Christo N.S. y de su Santissima Madre; $y$ de todos los Santos de que reza la Yglesia Romana, por todo el año, Madrid, Luis Sanchez.

\section{BIBLIOGRAFÍA}

Aguayo Сово, A. [1999]. «El Giraldillo. ¿Victoria Fidei?», Humanística, 11, 227-240.

Aguayo Coвo, A. [2013]. «La Casa de los Leones como emblema cántabro en El Puerto de Santa María. Análisis iconográfico de la fachada», Revista de Historia de El Puerto, 50, 79119.

Algarín GonzÁlez, I. [2015]. "Nuevas visiones y aportaciones en la pintura 'La Batalla de Clavijo', de la Iglesia de Santiago el Viejo de Sevilla», Laboratorio de Arte, 27, 145-172.

Algarín González, I. [2017]. «El mecenazgo de Gonzalo Argote de Molina: el contrato firmado con Mateo Pérez de Alesio", en A. Holguera Cabrera, E. Prieto Ustio, M. Uriondo LozAno (coords.), Coleccionismo, mecenazgo y mercado artístico en España e Iberoamérica, Sevilla, Universidad de Sevilla, 627-642.

Álvarez Márquez, M. C. [1992]. El mundo del libro en la iglesia catedral de Sevilla en el siglo XVI, Sevilla, Diputación Provincial de Sevilla.

IMAGO, NÚM. 10, 2018, 143-173 
Angulo Íñ Iguez, D. [1946]. Alejo Fernández, Sevilla, Laboratorio de Arte de la Universidad de Sevilla.

Angulo Íñiguez, D. [1951]. Pedro de Campaña, Sevilla, Laboratorio de Arte de la Universidad de Sevilla.

Barrios Aguilera, M. [2004]. Los falsos cronicones contra la historia (o Granada, corona martirial), Granada, Universidad de Granada.

Barrios Aguilera, M. [2011]. La invención de los libros plúmbeos. Fraude, historia y mito, Granada, Universidad de Granada.

Barrios Aguilera, M. y García-Arenal, M. (eds.) [2006]. Los plomos del Sacromonte. Invención $y$ tesoro, Valencia, Granada, Zaragoza, Universidad de Valencia, Universidad de Granada, Universidad de Zaragoza.

Bernales Ballesteros, J. [1973]. «Mateo Pérez de Alesio, pintor romano en Sevilla y Lima», Archivo Hispalense, 171-173, 221-271.

Boeglin, M. [2011]. «La expulsión de los moriscos de Andalucía y sus límites. El caso de Sevilla (1610-1613)", Cuadernos de historia moderna, 36, 89-107.

Cabrillana Ciézar, N. [1999]. Santiago matamoros, historia e imagen, Málaga, Diputación de Málaga.

Cardaillac, L. [2001]. "El mito de Santiago en España y América», en J. L. Castellano Castellano y F. SÁnchez-Montes (coords.), Congreso Internacional. Carlos V. Europeísmo y universalidad. Granada, mayo de 2000, Madrid, Sociedad Estatal para la Conmemoración de los Centenarios de Felipe II y Carlos V, vol. V, 107-131.

Castillo Utrilla, M. J. Del [1993]. «Los Patronatos de la familia Mañara en Sevilla», en D. Oliva Alonso (coord.), Restauración Casa-palacio de Miguel Mañara, Sevilla, Junta de Andalucía, 290-293.

CAstro, A. [1975]. La realidad histórica de España, México, Porrúa.

Castro Pérez, L., Prada Creo, E. de y Reboreda Morillo, S. [1995]. «Luparia y el culto de los santos Eufrasio y Torcuato", en M. A. Sinva Romero (dir.), Actas del Congreso de Estudios Jacobeos, Santiago de Compostela, Xunta de Galicia, 129-134.

Contreras y López de Ayala, J. de [1971]. «Santiago en Indias», en Editora Nacional, Santiago en España, Europa y América, Madrid, Editora Nacional, 491-557.

Cotarelo Valledor, A. [1945]. "Una nota para la biografía de Argote de Molina», Boletín de la Real Academia Española, 115, 225-228.

Cruz Valdovinos, J. M. [1999]. «Santiago, patrón de las Españas», en M. Calvo Domínguez (coord.), Santiago. La Esperanza. Palacio de Gelmírez, Santiago de Compostela, 27 de mayo - 31 de diciembre 1999, Santiago de Compostela, Xunta de Galicia, 123-139.

Díaz y Díaz, M. C. [2004]. "O mar nas vellas lendas xacobeas», en F. Singul Lorenzo y J. SuÁRez Otero (eds.), Até o confín do mundo. Diálogos entre Santiago e o mar. Do 27 de xullo ao 30 de setembro. Museo do mar de Galicia, Alcabre, Vigo, Vigo, Museo do Mar de Galicia, 123-128.

Domínguez García, J. [2008]. Memorias del futuro. Ideología y ficción en el símbolo de Santiago Apóstol, Madrid, Iberoamericana.

DomíngueZ ortiz, A. [1984]. Historia de Sevilla. La Sevilla del siglo XVII, Sevilla, Universidad de Sevilla.

Falcón Márquez, T. [1980]. La catedral de Sevilla. Estudio arquitectónico, Sevilla, Ayuntamiento de Sevilla.

Falque Rey, E. [2002]. «El llamado Privilegio de los Votos, fuente del Chronicon Mundi de Lucas de Tuy", Habis, 33, 573-577. 
Fernández Fuertes, T. [1999]. "Santiago en la Batalla de Clavijo», en M. Calvo Domínguez (coord.), Santiago el Mayor y la Leyenda Dorada. Museo de Belas Artes da Coruña, 23 de junio1 de septiembre 1999, Santiago de Compostela, Xunta de Galicia, 186-187.

Fernández Gallardo, L. [2005]. «Santiago Matamoros en la historiografía hispanomedieval: origen y desarrollo de un mito nacional», Medievalismo, 15, 139-174.

Fernández López, J. [2002]. Programas iconográficos de la pintura barroca sevillana del siglo XVII, Sevilla, Universidad de Sevilla.

Fernández Peón, J. M. [2008]. Religión y milicia. El Apóstol Santiago: su huella en la historia de España, Murcia, Universidad Católica San Antonio.

FÉRnÁndez RoJas, M. [2005-2006]. «Patrimonio artístico de las Órdenes militares que existieron en Sevilla», Archivo Hispalense, 267-272, 297-338.

Ferrer Garrofé, P. [1982]. Bernardo Simón de Pineda. Arquitectura en madera, Sevilla, Diputación Provincial de Sevilla.

García Iglesias, J. M. [2011]. Santiagos de Santiago. Dos apóstoles al final del Camino, Santiago de Compostela, Consorcio de Santiago, Alvarellos.

García Morales, M. V. y Nieto Alcaide, V. [2004]. "Santiago y la Monarquía española: orígenes de un mito de Estado", en Sociedad Estatal de Conmemoraciones Culturales, Santiago y la Monarquía de España (1504-1788). Colegio de Fonseca, Santiago de Compostela, 2 de julio - 19 de septiembre de 2004, Madrid, Sociedad Estatal de Conmemoraciones Culturales, 33-51.

Garrido Moreno, A. [1976]. "El grabado en Granada durante el siglo XVII. I. La calcografía», Cuadernos de arte de la Universidad de Granada, 13, 26-28, 9-218.

Gómez Darriba, J. [2014]. Iconografía de Santiago el Mayor en Sevilla, trabajo de fin de máster inédito, Sevilla, Universidad de Sevilla.

Gómez Darriba, J. [2017a]. «El apóstol Santiago y sus fuentes grabadas en la Sevilla de 1575 a $1750 »$, en A. Holguera Cabrera, E. Prieto Ustio y M. Uriondo Lozano (coords.), Coleccionismo, mecenazgo y mercado artístico en España e Iberoamérica, Sevilla, Universidad de Sevilla, 715-731.

Gómez Darriba, J. [2017b]. «Santiago Matamoros. Culto e iconografía en la Sevilla de 1535 a 1635", en B. Ballester Morell, A. Bernat Vistarini y J. T. Cull (eds.), Encrucijada de la palabra y la imagen simbólicas. Estudios de emblemática, Palma de Mallorca, José J. de Olañeta, 365-386.

GÓMEz LÓPEz, C. [2004]. «El apóstol Santiago y la corte: mentalidad, imagen y promoción artística», en Sociedad Estatal de Conmemoraciones Culturales, Santiago y la Monarquía de España (1504-1788). Colegio de Fonseca, Santiago de Compostela, 2 de julio - 19 de septiembre de 2004, Madrid, Sociedad Estatal de Conmemoraciones Culturales, 87-100.

GonzÁlez López, E. [1969]. Los políticos gallegos en la Corte de España y la convivencia europea. Galicia en los reinados de Felipe III y Felipe IV, Vigo, Galaxia.

Herbers, K. [2006]. Política y veneración de santos en la Península Ibérica. Desarrollo del «Santiago político», Pontevedra, Fundación Cultural Rutas del Románico.

Hidalgo Ogáyar, J. [1991]. "La imagen de Santiago 'Matamoros' en los manuscritos iluminados", Cuadernos de arte e iconografía, 7, 340-345.

Illán Martín, M. [2000]. "La colección pictórica del Conde del Águila», Laboratorio de Arte, $13,123-151$.

Ladero Quesada, M. A. [1989]. Historia de Sevilla. La ciudad medieval (1248-1492), Sevilla, Universidad de Sevilla. 
LinARES, L. [2007]. «Leyenda y figura de Santiago en dos hagiografías de principios del siglo XVII. Mauro Castellá Ferrer y Hernando Ojea Gallego y sus Historias del Apóstol Santiago", en A. Arizaleta, F. Cazal, L. González Fernández, M. Güell y T. Rodríguez (eds.), Pratiques hagiographiques dans l'Espagne du Moyen Âge et du Siècle d'Or. II, Tolouse, CNRS, Université de Tolouse-Le Mirail, 521-542.

LinARES, L. [2008]. Les saints Matamores en Espagne, au Moyen Âge et au Siècle d'Or (XIIèmeXVIIème siècles). Histoire et Représentations, tesis doctoral inédita, Tolouse, Université Tolouse le Mirail - Tolouse II, t. I.

LinAREs, L. [2012]. “`Santiago y cierra, España!’», Les Cahiers de Framespa, <journals.openedition.org/framespa/1552>8-3-2018.

LinARES, L. [2013]. «Los santos matamoros en la memoria de las ciudades: la celebración de un origen mítico", en F. RaYnié y T. Rodríguez (eds.), Dire, taire, masquer les origines dans la péninsule Ibérique, du Moyen Âge au Siècle d'Or, Tolouse, Méridiennes, CNRS-Université de Tolouse-Le Mirail, 63-72.

LinARES, L. [2014]. "Le difficile héritage de la Reconquête espagnole: Saint Jacques Matamore, entre occultation et réappropriation», en J. Alonso Carballés y A. D. Wells (eds.), Traces, Empreintes, Monuments, quels lieux pour quelles mémories? De 1989 à nos jours, Limoges, PULIM, 129-141.

López López, R. J. [2007]. «Un ejemplo de propaganda bélica: rogativas y festejos en Santiago por la toma de Orán en 1732», Sémata, 19, 95-134.

López López, R. J. [2008]. «La pervivencia de un mito bélico en la España Moderna: la imagen de Santiago Caballero», en D. GonzÁlez Cruz (ed.), Religión y conflictos bélicos en Iberoamérica, Sevilla, Universidad Internacional de Andalucía, 41-73.

Maravall, J. A. [1975]. Estudios de historia del pensamiento español. Serie tercera. Siglo XVII, Madrid, Cultura Hispánica.

Marchena Hidalgo, R. [1998]. Las miniaturas de los libros de coro de la catedral de Sevilla: el siglo $X V I$, Sevilla, Universidad de Sevilla, Fundación Focus-Abengoa.

Marchena Hidalgo, R. [2005]. Pedro de Palma, miniaturista del siglo XVI, Sevilla, Universidad de Sevilla.

Marchena Hidalgo, R. [2011]. "La iluminación al servicio del estamento privilegiado: las ejecutorias de hidalguía», Laboratorio de Arte, 23, 125-146.

Márquez Villanueva, F. [2004]. Santiago: trayectoria de un mito, Barcelona, Bellaterra.

Martínez Ripoll, A. [1978]. Francisco de Herrera 'el Viejo', Sevilla, Diputación Provincial de Sevilla.

Mayer, A. L. [2010]. La escuela sevillana de pintura. Aportaciones a su historia, Sevilla, Cajasol.

Mena Calvo, J. M. De [2010]. Historia de Sevilla, Barcelona, Plaza \& Janés.

Millares Carlo, A. y Palma Chaguaceda, A. [1973]. El historiador Gonzalo Argote de Molina. Estudio biográfico, bibliográfico y crítico, Las Palmas, Ayuntamiento de las Palmas.

Monterroso Montero, J. M. [1997]. «Santiago, San Millán y San Raimundo: Milites Christi», en F. Singul Lorenzo (ed.), Santiago, Al-Andalus: diálogos artísticos para un milenio. Conmemoración do Milenario da Restauración da cidade de Santiago despóis da "razzia de Almanzor" (997-1997). Mosteiro de San Martiño Pinario, Santiago de Compostela, 2 xuño - 31 agosto de 1997, Santiago de Compostela, Xunta de Galicia, 485-500. 
Monterroso Montero, J. M. [2004]. «A la sombra de Santiago. La afirmación del culto jacobeo y su identificación con la Monarquía durante la Edad Moderna», en Sociedad Estatal de Conmemoraciones Culturales, Santiago y la Monarquía de España (1504-1788). Colegio de Fonseca, Santiago de Compostela, 2 de julio - 19 de septiembre de 2004, Madrid, Sociedad Estatal de Conmemoraciones Culturales, 53-70.

Morales Martínez, A. J. [1984]. La Sacristía Mayor de la Catedral de Sevilla, Sevilla, Diputación Provincial de Sevilla.

Morales Padrón, F. [1989]. Historia de Sevilla. La ciudad del Quinientos, Sevilla, Universidad de Sevilla.

Olivares Torres, E. [2011]. Iconografia de San Jaume Cavaller. El retaule major d'Algemesí, Algemesí, Ajuntament d'Algemesí.

Olivares Torres, E. [2015]. L'ideal d'evangelització guerrera. Iconografia dels cavallers sants, tesis doctoral inédita, Valencia, Universitat de València.

Olivera Serrano, C. [2013]. «Realeza castellana y culto jacobeo a fines del siglo XV: la recuperación del Santiago político", en S. López Martínez-Morás, M. Meléndez Cabo y G. Pérez BARCAla (eds.), Identidad europea e intercambios culturales en el Camino de Santiago (siglos XI$X V$ ), Santiago de Compostela, Universidade de Santiago de Compostela, 13-26.

Oтте, Е. [2003]. «Diego Caballero, funcionario de la Casa de la Contratación», en A. Acosta Rodríguez y otros (coords.), La Casa de la Contratación y la navegación entre España y las Indias, Sevilla, Universidad de Sevilla, CSIC, Fundación El Monte, 315-339.

Palomero Páramo, J. M. [1983]. El retablo sevillano del Renacimiento: análisis y evolución (15601629), Sevilla, Diputación Provincial de Sevilla.

Peinado Santaella, R. G. [1976-1977]. «La Orden de Santiago en Sevilla», Cuadernos de Estudios Medievales, 4-5, 179-201.

Pepe Sarno, I. [1967]. «La biblioteca di Argote de Molina. Tentativo de catalogo della sezione manoscritti», Studi di Letteratura spagnola, 1967, 165-262.

Péricard-Méa, D. [2011]. Le Matamore. Mythe, images et réalités, Cahors, La Louvre.

Pita Andrade, J. M. [1971]. "Santiago en España, fuera de los caminos de peregrinación», en Editora Nacional, Santiago en España, Europa y América, Madrid, Editora Nacional, 325488.

Porres Benavides, J. [2015]. "Pintura sevillana del siglo XVIII. Nuevas aportaciones al catálogo de Ruiz Soriano", en M. A. Rodríguez Miranda (coord.), Nuevas perspectivas sobre el Barroco Andaluz. Arte, Tradición, Ornato y Símbolo, Córdoba, Asociación «Hurtado Izquierdo", 799-814.

Portela Sandoval, F. J. [2004]. «Santiago, miles Christi y caballero de las Españas», en Sociedad Estatal de Conmemoraciones Culturales, Santiago y la Monarquía de España (1504-1788). Colegio de Fonseca, Santiago de Compostela, 2 de julio - 19 de septiembre de 2004, Madrid, Sociedad Estatal de Conmemoraciones Culturales, 71-85.

Precedo Lafuente, M. J. [2008]. "Las imágenes ecuestres de Santiago el Mayor», en S. L. Pérez López (coord.), Plenitudo Veritatis. Homenaje a Mons. Romero Pose, Santiago de Compostela, Instituto Teológico Compostelano, 521-527.

Ramos Suárez, M. A. [2011]. "La fachada de la iglesia de San Jorge del Hospital de la Santa Caridad de Sevilla», en J. Fernández López y L. Malo Lara (eds.), Estudios sobre Miguel Mañara. Su figura y su época, santidad, historia y arte, Sevilla, Hermandad de la Santa Caridad, 493-510.

RÉAu, L. [1998]. Iconografía del arte cristiano, Barcelona, Ediciones del Serbal, t. II, vol. V. 
Rey Castelao, O. [1985]. La historiografía del Voto de Santiago. Recopilación crítica de una polémica histórica, Santiago, Universidad de Santiago.

Rey Castelao, O. [2006]. Los mitos del apóstol Santiago, Santiago de Compostela, Vigo, Consorcio de Santiago, Nigra Trea.

Rey Castelao, O. [2007]. «La disputa del patronazgo de la Monarquía: Santiago o Santa Teresa", en J. Martínez Millán y M. A. Visceglia (dirs.), La monarquía de Felipe III: la Casa del Rey, Madrid, Fundación MAPFRE, Instituto de Cultura, vol I, 227-246.

Rey Castelao, O. [2015]. "Teresa, patrona de España», Hispania Sacra, 136, 531-573.

Reyes Gómez, F. de los, Santos Fernández, C. [2004]. Impresos en torno al patronato de Santiago. Siglo XVII, Santiago de Compostela, Xunta de Galicia.

Rodríguez Blanco, D. [1979]. "El monasterio de Santiago de la Espada de Sevilla», Historia. Instituciones. Documentos, 6, 309-324.

Rodríguez Blanco, D. [2012]. "Las Órdenes Militares en el Reino de Sevilla en la Edad Media», Historia. Instituciones. Documentos, 39, 287-324.

Rodríguez Blanco, D. [2013]. «Las Órdenes Militares en el Reino de Sevilla en la Edad Media. El contexto de la Encomienda Santiaguista de Estepa», en Ayuntamiento de Estepa, Cuadernos de Estepa. $N^{\circ}$ 01. Actas de las VII Jornadas sobre Historia de Estepa. De la Antigüedad Tardía a la Encomienda Santiaguista. La época medieval en el centro de Andalucía. Sesiones celebradas el 15, 16 y 17 de septiembre de 2008, Estepa, Ayuntamiento de Estepa, 277-340.

Rodríguez Culebras, R. [1999]. "Santiago en la Batalla de Clavijo», en M. Calvo Domínguez (coord.), Todos con Santiago. Patrimonio eclesiástico. Monasterio de San Martín Pinario. Museo Diocesano Santiago de Compostela. 18 de marzo - 18 mayo 1999, Santiago de Compostela, Xunta de Galicia, 180-181.

Ruiz García, E. [2006]. "La carta ejecutoria de hidalguía: un espacio geográfico privilegiado», En la España medieval, 1 (extra), 251-276.

SaAvedra Fernández, P. [1999]. "Santiago y cierra España», en M. Calvo Domínguez (coord.), Santiago el Mayor y la Leyenda Dorada. Museo de Belas Artes da Coruña, 23 de junio - 1 de septiembre 1999, Santiago de Compostela, Xunta de Galicia, 129-139.

SÁnchez y Pineda, C. [1936]. "La miniatura en la Sala González Abreu del Museo de Bellas Artes de Sevilla", Boletín de Bellas Artes, 3, 62-67.

Santos Fernández, C. [2008]. "Pesquisas realizadas en Sevilla para identificar al autor y al impresor de la contradicción a la carta del arzobispo Pedro de Castro en defensa del patronato de Santiago», Historia. Instituciones, Documentos, 35, 321-353.

Serra Giráldez, S. [1990]. Francisco Meneses Osorio, discípulo de Murillo, Sevilla, Diputación Provincial de Sevilla.

Serrera Contreras, J. M. [1984]. "Pinturas y pintores del siglo XVI en la catedral de Sevilla», en Guadalquivir, La catedral de Sevilla, Sevilla, Guadalquivir, 353-404.

Serrera Contreras, J. M. y Valdivieso González, E. [1985]. Historia de la pintura española. Escuela sevillana del primer tercio del siglo XVII, Madrid, CSIC.

Sicart Giménez, A. A. [1978]. La miniatura medieval en Galicia, Santiago de Compostela, Universidad de Santiago.

Sicart Giménez, A. A. [1981]. Pintura medieval: la miniatura, Santiago de Compostela, Arte Galega Sánchez Cantón.

Sicart Giménez, A. A. [1982]. "La iconografía de Santiago ecuestre en la Edad Media», Compostellanum, 27, 11-32. 
Steppe, K. J. [1985]. «L'iconographie de Saint Jacques le Majeur (Santiago)», en Credit Communal, Santiago de Compostela: 1000 ans de pélerinage européen, Belgique, Credit Communal, 129-153.

Valdivieso GonzÁlez, E. [1978]. Juan de Roelas, Sevilla, Diputación Provincial de Sevilla.

VAldivieso GonzÁLEz, E. [1988]. Juan de Valdés Leal, Sevilla, Guadalquivir.

Valdivieso GonzÁlez, E. [2002]. Historia de la pintura sevillana. Siglos XIII al XIX, Sevilla, Guadalquivir.

Valdivieso González, E. [2008]. Pedro de Campaña, Sevilla, Patronato de la Fundación Sevillana Endesa.

Varela Jácome, B. [1965]. «La temática jacobea en las gestas y el romancero», Compostellanum, 10, 775-804.

Vázquez Castro, J. [2014]. La peregrinación a Santiago de Diego de Guzmán. Diario inédito de 1610, Santiago de Compostela, Alvarellos, Xunta de Galicia.

Yzquierdo PerRín, R. [2005]. Símbolos jacobeos, Vigo, Cardeñoso.

ZuCKeR, M. [1984]. The Illustrated Bartsch. Early Italian Masters, New York, Abaris Books. 
